\title{
ANÁLISIS SOBRE LA CONSTITUCIONALIDAD DE LA LEY DEL "ARREPENTIDO"
}

\section{Gregorio José Uriburu}

\author{
Ministerio Público Fiscal de la Nación \\ gregoriouriburu@hotmail.com
}

Recibido: 01/03/2021

Aceptado: $13 / 04 / 2021$

\section{Resumen}

Por medio de la Ley 27304, el Congreso de la Nación Argentina sancionó un nuevo instituto de delación premiada aplicable a un amplio catálogo de delitos, en el cual el imputado arrepentido recibe el beneficio de reducción de las escalas penales a cambio de brindar información incriminante contra terceros. En el presente artículo se analizan críticamente las objeciones a la constitucionalidad de esta ley del "arrepentido" formuladas tanto por la doctrina como en la jurisprudencia, que fueron fundadas en tres postulados constitucionales: la garantía contra la autoincriminación forzada, el principio de igualdad ante la ley y la garantía contra la aplicación retroactiva de la ley penal más gravosa.

Palabras clave: derecho penal, delación premiada, control de constitucionalidad, autoincriminación forzada, igualdad ante la ley, irretroactividad de la ley penal.

\section{Constitutional Review of the Law of the "Repentant Defendant"}

\begin{abstract}
By the Law no. 27.304, the National Congress of Argentina enacted a new regulation of rewarded delation that can be applied to a wide range of crimes, in which the "repentant defendant" receives the benefit of the reduction of the sentencing range in exchange for providing incriminating information regarding third parties. The present article will critically analyze the objections to the constitutionality of this law of the "repentant defendant" as formulated both by the doctrine and in jurisprudence, which were grounded on three constitutional postulates: the guarantee against self-incrimination, the principle of equality under the law, and the guarantee against the exertion of more severe ex post facto laws.
\end{abstract}


Key words: criminal law, rewarded delation, constitutional review, forced self-incrimination, equality under the law, ex post facto law.

\section{Introducción ${ }^{1}$}

La Ley 27304, que sancionó el instituto del "arrepentido", "imputado colaborador" o "delación premiada” -términos que se utilizarán de forma equivalente-, trajo aparejada una álgida discusión en torno a su moralidad, su conveniencia y su adecuación a los principios del derecho penal liberal y el Estado de derecho, así como a las normas de nuestra Constitución Nacional y tratados internacionales de derechos humanos.

Esta polémica doctrinal, que ya se venía desarrollando desde anteriores regulaciones del mencionado instituto para una reducida cantidad de delitos, se vio cristalizada en una minuciosa sentencia dividida de la Sala I de la Cámara Federal de Casación Penal en la investigación conocida como la "Causa de los Cuadernos", ${ }^{2}$ a la que se hará especial referencia, resultando ineludible para la consideración del tema de este trabajo por su relevancia institucional y política. En esta causa criminal, en la que se acusa a más de cien empresarios contratistas del Estado y funcionarios públicos de haber intervenido en una de las mayores tramas de corrupción del país, ha sido fundamental para la investigación la declaración de numerosos imputados arrepentidos. Ante impugnaciones relativas a la validez de dichos acuerdos presentados por las defensas de tres imputados, incluyendo las del exministro de Planificación Federal, Inversión Pública y Servicios y la del expresidente de la Unión Industrial Argentina, por mayoría se resolvió declarar la constitucionalidad de la Ley 27304.

El profundo debate reflejado en la sentencia citada resulta una ocasión propicia para analizar y aportar argumentos relativos a la constitucionalidad de este instituto.

\section{Breve reseña de la Ley 27304}

La figura del arrepentido o imputado colaborador no es novedosa en nuestra legislación a partir de nuestro período constitucional. Ya en el artículo 4 de la

1 Agradezco los comentarios de Manuel José García-Mansilla e Ignacio Abel Uriburu, quienes siempre me incentivan a escribir.

2 Cámara Federal de Casación Penal, Sala I: De Vido, Julio Miguel y otros s/recurso de casación, 30/11/2020, [CFP 9608/2018/100, Registro 1663/20]. 
Ley $49^{3}$ de 1863 se estableció que quedará exento de la pena prevista para el delito de traición y conspiración a la traición "el que revelase la conspiración a la autoridad pública antes de haber comenzado el procedimiento”. Por su parte, en el Proyecto de Código Penal presentado por Carlos Tejedor en 1868 -adoptado por ocho provincias (Zorraquín Becú, 1988)- ${ }^{4}$ se preveía la atenuación prudencial de la pena cuando el imputado "... revela la existencia de nuevos culpables desconocidos la justicia, ó dá de propio motu los medios y la ocasion de prenderlos", aunque ello no implicaba la posibilidad de cambiar el tipo de pena ni alterar la escala penal. ${ }^{5}$

Más recientemente, dicha figura fue receptada con distintas variantes, beneficiando al imputado ya sea con la eximición de la pena o con la reducción de la escala penal. Incluso, algunas regulaciones previeron un delito para quienes proporcionen datos falsos. Así entonces, la delación premiada fue legislada para el delito de traición a la patria ${ }^{6}$ en el Código Penal y en las leyes de "penalidades para los que atentan contra la seguridad de la Nación", ${ }^{7}$ estupefacientes, ${ }^{8}$ terrorismo, ${ }^{9}$ privación ilegal de la libertad coactiva y secuestro extorsivo, ${ }^{10}$ trata

3 Ley 49 de Delitos cuyo juzgamiento compete a los Tribunales Nacionales, sancionada el 14 de septiembre de 1863. Cfr. Registro Nacional de la República Argentina, tomo V, núm. 5968.

4 Cabe destacar que la facultad de las provincias para dictar leyes penales hasta la sanción de un Código Penal por parte del Gobierno federal -lo que ocurrió en 1886 con la Ley 1920- se desprendía del artículo 108 de la Constitución Nacional (actualmente artículo 126) en tanto se establecía que: "Las provincias no ejercen el Poder delegado a la Nación. No pueden [...] dictar los códigos Civil Comercial, Penal y de Minería, después que el Congreso los haya sancionado".

5 Artículos 188, 189 y 190 del Proyecto de Código Penal presentado por Carlos Tejedor. Se conserva la ortografía original.

6 De manera similar a la Ley 49, el artículo 216 del Código Penal pune desde su sanción, en 1921, a la conspiración para cometer el delito de traición, es decir, adelanta la punibilidad a los actos preparatorios del delito de traición. Seguidamente, el artículo 217 del Código Penal establece que: "Quedará eximido de pena el que revelare la conspiración a la autoridad, antes de haberse comenzado el procedimiento"; norma necesaria, ya que no le es aplicable la eximición de la pena por el instituto del desistimiento de la tentativa por consumarse el delito con los actos preparatorios.

7 Ley 13985, BO 16/10/1950, artículo 14, párr. 2ª que establecía que: "Podrá ser declarado exento de sanción penal todo aquel que luego de haber consumado el delito lo denuncie a las autoridades civiles o militares y procure el arresto de los coautores o cómplices".

8 Ley 23737, artículo 29 ter, conforme modificación de la Ley 24424, BO 09/01/1995, previendo la reducción a la mitad del mínimo de la pena o eximición.

9 Ley 25241, BO 17/03/2000, artículos 2 a 6, reduciendo la escala penal como en la tentativa o limitándola a la mitad. Además, se previó un tipo penal por el cual se dispuso que: "Será reprimida con prisión de uno (1) a tres (3) años cualquiera de las personas que se acojan a esta ley y formulen señalamientos falsos o proporcionen datos inexactos sobre terceras personas".

10 Ley 25742, BO 20/06/2003, artículo 2, que otorgó la facultad de reducir la escala penal en un tercio del máximo y la mitad del mínimo. 
de personas,${ }^{11}$ desaparición forzada de personas ${ }^{12}$ y lavado de activos de origen delictivo. ${ }^{13}$ Posteriormente, se previó la posibilidad de realizar un acuerdo de colaboración eficaz para las personas jurídicas. ${ }^{14}$

Respecto al ámbito internacional, por el artículo 26 de la Convención de las Naciones Unidas contra la Delincuencia Organizada Transnacional ${ }^{15}$ y el artículo 37 de la Convención de las Naciones Unidas contra la Corrupción ${ }^{16}$ se impuso de manera similar la obligación del Estado de adoptar medidas apropiadas para alentar a las personas que participen o hayan participado en la comisión de delitos de corrupción o en grupos delictivos organizados a que proporcionen a las autoridades competentes información útil con fines investigativos y probatorios, y a que les presten ayuda efectiva y concreta que pueda contribuir a privar a los delincuentes del producto del delito, así como a recuperar ese producto. Además, se previó el deber del Estado de considerar la posibilidad de prever la mitigación de la pena e incluso la inmunidad penal de toda persona acusada que preste cooperación sustancial en la investigación o el enjuiciamiento de los delitos tipificados con arreglo a dichas convenciones.

Ante este panorama, y teniendo en cuenta expresamente la obligación derivada de la Convención de las Naciones Unidas contra la Corrupción, ${ }^{17}$ el 2 de

11 Ley 26364, BO 30/04/2008, artículo 12, modificatorio del artículo 41 ter del Código Penal, previendo que las escalas penales previstas en los artículos 142 bis, 145 bis, 145 ter y 170 del Código Penal podrán reducirse en un tercio del máximo y en la mitad del mínimo, y en el caso de pena de prisión o reclusión perpetua, podrá aplicarse prisión o reclusión de ocho a quince años.

12 Ley 26679, BO 09/05/2011, que incorporó el artículo 142 ter del Código Penal, tipificando el delito de desaparición forzada de personas y previendo que podrá reducirse en un tercio del máximo y en la mitad del mínimo respecto a los autores o partícipes que liberen con vida a la víctima o proporcionen información que permita su efectiva aparición con vida.

13 Ley 26683, BO 21/06/2011, artículo 22, incorporando el artículo 31 de la Ley 25246, BO 10/05/2000, sobre Encubrimiento y Lavado de Activos de Origen Ilícito, que remitía al instituto del imputado colaborador previsto por los artículos 2 a 7 de la Ley 25241 de hechos de terrorismo, antes citada.

14 Ley 27401 de Régimen de Responsabilidad Penal Aplicable a las Personas Jurídicas Privadas, BO 01/12/2017, artículos 16 a 21.

15 Adoptada en Palermo en el año 2000 y aprobada por la Argentina en el año 2002 por la Ley 25632, BO 30/08/2002.

16 Adoptada en Nueva York el 31 de octubre de 2003, aprobada por la Argentina en el año 2006 por la Ley 26097, BO 09/06/2006.

17 Cfr. Dictamen de la Comisión de Justicia y Asuntos Penales y de Seguridad Interior y Narcotráfico del Senado de la Nación, Orden del Día N605, 31/08/2016; y versión taquigráfica e inserciones de la Sesión Ordinaria Especial de la Cámara de Diputados de la Nación del 23/06/2016, y versión taquigráfica de la Cámara de Senadores de la Nación 13a Reunión -5ª Sesión ordinaria- 07/09/2016. 
noviembre de 2016 se sancionó la Ley 27304, conocida popularmente como la "ley del arrepentido". Entre otras disposiciones, esta ley modificó el artículo 41 ter del Código Penal e incorporó un nuevo tipo penal en el artículo 276 bis del mismo cuerpo legal.

Según esta nueva redacción del artículo 41 ter del Código Penal, ${ }^{18}$ se prevé que una persona imputada de ser autora o partícipe de un delito, que se encuentre vinculado con un catálogo de delitos taxativamente enumerados, podrá obtener como beneficio la reducción de las escalas de las penas de prisión previstas para las de la tentativa -es decir, de un tercio a la mitad- ${ }^{19}$ o quince años de prisión para las penas perpetuas de esta especie. Para ello, durante la sustanciación del proceso del que sea parte, deberá brindar información o datos precisos, comprobables y verosímiles que

contribuyan a evitar o impedir el comienzo, la permanencia o consumación de un delito; esclarecer el hecho objeto de investigación u otros conexos; revelar

18 Artículo 41 ter del Código Penal: "Las escalas penales podrán reducirse a las de la tentativa respecto de los partícipes o autores por algún delito de los detallados a continuación en este artículo, cuando durante la sustanciación del proceso del que sean parte, brinden información o datos precisos, comprobables y verosímiles.

El proceso sobre el cual se aporten datos o información deberá estar vinculado con alguno de los siguientes delitos: a) Delitos de producción, tráfico, transporte, siembra, almacenamiento y comercialización de estupefacientes, precursores químicos o cualquier otra materia prima para su producción o fabricación previstos en la ley 23.737 o la que en el futuro la reemplace, y la organización y financiación de dichos delitos; b) Delitos previstos en la sección XII, título I del Código Aduanero; c) Todos los casos en los que sea aplicable el artículo 41 quinquies del Código Penal; d) Delitos previstos en los artículos 125, 125 bis, 126, 127 y 128 del Código Penal; e) Delitos previstos en los artículos 142 bis, 142 ter y 170 del Código Penal; f) Delitos previstos en los artículos 145 bis y 145 ter del Código Penal; g) Delitos cometidos en los términos de los artículos 210 y 210 bis del Código Penal; h) Delitos previstos en los capítulos VI, VII, VIII, IX, IX bis y X del título XI y en el inciso 5 del artículo 174, del Código Penal; i) Delitos previstos en el título XIII, del libro segundo, del Código Penal.

Para la procedencia de este beneficio será necesario que los datos o información aportada contribuyan a evitar o impedir el comienzo, la permanencia o consumación de un delito; esclarecer el hecho objeto de investigación u otros conexos; revelar la identidad o el paradero de autores, coautores, instigadores o partícipes de estos hechos investigados o de otros conexos; proporcionar datos suficientes que permitan un significativo avance de la investigación o el paradero de víctimas privadas de su libertad; averiguar el destino de los instrumentos, bienes, efectos, productos o ganancias del delito; o indicar las fuentes de financiamiento de organizaciones criminales involucradas en la comisión de los delitos previstos en el presente artículo.

Cuando el delito atribuido al imputado estuviere reprimido con prisión y/o reclusión perpetua, la pena sólo podrá reducirse hasta los quince (15) años de prisión.

La reducción de pena no procederá respecto de las penas de inhabilitación o multa”.

19 A mi entender, esta forma de interpretar la norma debe regir incluso en relación con los delitos previstos por el Código Aduanero, cuyo artículo 872 establece que: "La tentativa de contrabando será reprimida con las mismas penas que correspondan al delito consumado". De lo contrario, no habría beneficio especial alguno para los delatores premiados, atacando la razonabilidad de la norma. 
la identidad o el paradero de autores, coautores, instigadores o partícipes de estos hechos investigados o de otros conexos; proporcionar datos suficientes que permitan un significativo avance de la investigación o el paradero de víctimas privadas de su libertad; averiguar el destino de los instrumentos, bienes, efectos, productos o ganancias del delito; o indicar las fuentes de financiamiento de organizaciones criminales involucradas en la comisión de los delitos previstos en el presente artículo.

Asimismo, respecto al objeto de la declaración del imputado colaborador, el artículo 3 de la Ley 27304 establece que "[l]a información que se aporte deberá referirse únicamente a los hechos ilícitos de los que haya sido partícipe y a sujetos cuya responsabilidad penal sea igual o mayor a la del imputado arrepentido”. Además, en el mismo artículo se prohíbe el acogimiento a este instituto a los "funcionarios que hayan ejercido o estén ejerciendo cargos susceptibles del proceso de juicio político de acuerdo a lo establecido por la Constitución Nacional" y a los "procesos en los que se investiguen delitos de lesa humanidad". Dentro de un plazo no superior a un año, el juez o el fiscal deberá corroborar el cumplimiento de las obligaciones que el imputado arrepentido hubiera contraído en el marco del acuerdo, especialmente la verosimilitud y utilidad, total o parcial, de la información que hubiera proporcionado.

Esta declaración, si bien no se aclara si deberá realizarse bajo juramento de decir verdad, implica un deber de decir verdad, toda vez que se prevé un delito especial para este acto en el artículo 276 bis del Código Penal. Por esta norma se establece que: "Será reprimido con prisión de cuatro (4) a diez (10) años y con la pérdida del beneficio concedido el que, acogiéndose al beneficio del artículo 41 ter, proporcionare maliciosamente información falsa o datos inexactos”. Es decir, no toda declaración falsa o inexacta del imputado colaborador será delictiva, sino solamente aquella que haya sido efectuado con dolo directo.

Por otro lado, de conformidad con los artículos 6 a 10 de la Ley 27304, se ordena que se guarden formas para las distintas etapas del acuerdo entre el imputado colaborador/arrepentido -con asistencia de su defensor- y el fiscal. En efecto, se establece que las declaraciones del imputado conteniendo la información objeto del acuerdo deberán "registrarse a través de cualquier medio técnico idóneo que garantice su evaluación posterior”. Asimismo, se prevé que el acuerdo de colaboración deberá celebrarse por escrito entre el fiscal y el imputado con asistencia de su defensor, para ser homologado por el juez de la causa en una audiencia convocada al efecto.

En este orden, en cuanto a los efectos de la celebración de un acuerdo de 
colaboración, se prescribe, además del beneficio de reducción de la escala de pena privativa de la libertad, que el juez tiene la facultad de valorarlo "a los fines de la excarcelación o de la exención de prisión, de acuerdo a las normas procesales comunes" (artículo 4). En contraste, se manda al juez a que valore el acuerdo "a los fines de dictar las medidas cautelares del proceso respecto de las personas involucradas por el imputado arrepentido" (artículo 12).

Por último, se ordena de forma enfática en el artículo 15 que no se

podrá dictar sentencia condenatoria fundada únicamente en las manifestaciones efectuadas por el imputado arrepentido. Para la asignación de responsabilidad penal sobre la base de estos elementos, el órgano judicial deberá indicar de manera precisa y fundada la correlación existente entre esas manifestaciones y las restantes pruebas en que se sustenta la condena. La materialidad de un hecho delictivo no podrá probarse únicamente sobre la base de esas manifestaciones.

\section{Análisis de las impugnaciones a su constitucionalidad}

A efectos de analizar las pretendidas tachas de inconstitucionalidad de la Ley 27304, esbozadas en la doctrina y principalmente en el profuso voto disidente del fallo De Vido de la Cámara Federal de Casación Penal, se sistematizarán las distintas posiciones críticas alrededor de la garantía o principio jurídico invocado, intentando rescatar las tesis de la manera más robusta posible. A tal fin, se dejarán de lado los argumentos de posturas referidas a vicisitudes concretas de casos que no hacen al estudio constitucional de la norma sino a nulidades procesales, o de argumentos que bajo el ropaje del examen de constitucionalidad en realidad implican otro tipo de agravio o que involucran una perversión de la norma atacada, como podría ser la pretendida utilización del instituto en el caso concreto como una "persecución política" (Alén, 2018), o una "extorsión procesal supuestamente legalizada”, tal como se alegó en la citada causa.

\subsection{Prohibición de la autoincriminación forzada}

Ahora bien, un primer agravio constitucional contra el instituto del imputado colaborador es aquel referido a la violación a la garantía de la prohibición de la obligación a la autoincriminación.

Sin lugar a dudas, nuestra Constitución Nacional prevé dentro de las garantías penales la prohibición de la autoincriminación forzada. Ello se desprende 
primeramente de la letra del artículo 18 de nuestra carta magna, que establece que: "Nadie puede ser obligado a declarar contra sí mismo".

Además, dicha garantía se encuentra contenida en tratados internacionales de derechos humanos con jerarquía constitucional. En efecto, el artículo 8.2.g) de la Convención Americana sobre Derechos Humanos dispone que: “... 2. Toda persona inculpada de delito tiene derecho a que se presuma su inocencia mientras no se establezca legalmente su culpabilidad. Durante el proceso, toda persona tiene derecho, en plena igualdad, a las siguientes garantías mínimas: [...] g) derecho a no ser obligado a declarar contra sí mismo ni a declararse culpable...”. A ello, cabe agregar que el artículo 8.3 de la misma Convención manda que: "La confesión del inculpado solamente es válida si es hecha sin coacción de ninguna naturaleza”.

Por su parte, el Pacto Internacional de Derechos Civiles y Políticos ordena en su artículo 14.3.g) que "... Durante el proceso, toda persona acusada de un delito tendrá derecho, en plena igualdad, a las siguientes garantías mínimas: [...] g) A no ser obligada a declarar contra sí misma ni a confesarse culpable...”.

Esta garantía se encuentra también prevista de manera similar tanto en instrumentos específicos del derecho internacional de derechos humanos como en el artículo 40.2.iv) de la Convención sobre los Derechos del Niño -con jerarquía constitucional- y en los artículos 55.1.a) y b) y 55.2.b) del Estatuto de Roma para la Corte Penal Internacional.

Por último, debe señalarse que dicho principio posee una similar recepción en el derecho internacional humanitario. Verbigracia, en el artículo 99 del Tercer Convenio de Ginebra del 12/08/1949, relativo al trato debido a los prisioneros de guerra, así como en el artículo 75.4.f) del Protocolo Facultativo I y el artículo 6.2.f) de su protocolo Facultativo II.

\subsubsection{Críticas a la constitucionalidad del instituto}

Así entonces, en base a las normas precitadas, se critica el instituto del imputado colaborador porque, tal como se encuentra regulado en la Ley 27304, su aplicación implicaría una coacción incompatible con la garantía contra la autoincriminación forzada. Así, se alegan tres fuentes de coacción moral: i) el beneficio de reducción de la escala penal para quien se "arrepienta" y colabore; ii) el beneficio para quien se acoja al instituto de obtener la libertad durante el proceso; y iii) el delito previsto por el artículo 276 bis relativo al suministro malicioso de información falsa o inexacta por parte del imputado colaborador. 
Respecto al primer punto, relativo a la disminución de la pena para el imputado colaborador como violatorio de la garantía de prohibición de la autoincriminación forzada, Marcelo Sancinetti (2016) argumentó que, en tanto se estaría previendo una pena más grave para quien no confiese su delito, de ella se desprende una verdadera coacción moral que vicia la voluntad. ${ }^{20}$ Sostiene el citado autor:

Es una falacia el argumentar que, en tanto el autor o partícipe de un delito concurran "voluntariamente" a reconocer su hecho, entonces no habría ninguna lesión al art. 18, CN, [...] Pero si uno realmente se atiene al principio de que, en un Estado de Derecho, nadie está obligado a penarse a sí mismo, entonces, tampoco puede sufrir un "aumento de pena" por no declararse culpable. Y ocurre que si, respecto de quien sí confiesa hay una "reducción", ello implica necesariamente -en términos comparativos- que para el que no reconoce su culpabilidad (supóngase, en sí merecida) hay un incremento de su punición, por lo que, como saldo, se lo presiona a declarar contra sí mismo so pena de ser incrementada su punición por no declararse "voluntariamente" culpable. Por consiguiente, todo estímulo a la auto-incriminación implica una lesión al art. 18, CN ("principio nemo tenetur"). (p. 8)

Como se adelantó, otros no critican la reducción de la escala penal en sí, sino el supuesto beneficio inmediato relativo a la obtención de la libertad para el imputado que se encuentra en prisión preventiva, considerándola como una moneda de cambio para compeler a los imputados a declarar en su contra y de sus posibles cómplices (Rusconi, 2018). En similar sentido a Díaz Cantón (2018), esta es la tesitura sostenida por la jueza Ana María Figueroa en su voto en la sentencia De Vido, quien entiende que la facultad del juez de valorar el acogimiento a este instituto a los fines de la excarcelación es limitadora de la voluntariedad del imputado en tal acto.

En efecto, luego de fundar la posición relativa a que la restricción de la libertad durante el proceso, de acuerdo con nuestra legislación interna y la internacional, solamente procede ante la existencia de riesgos procesales, sostuvo la citada jueza:

Resulta éticamente inaceptable en un Estado de derecho, y contrario a las disposiciones convencionales y constitucionales tal vinculación de acogerse a la figura del arrepentido para conservar la libertad durante el proceso o de lo contrario cumplir con prisión cautelar, dado que esta última, sólo puede ser fundada válidamente en una estricta valoración de la existencia de riesgos para el proceso.

20 En un sentido similar, respecto al proyecto de ley contra actividades terroristas, Neira (1997). 
Extremando el razonamiento, podría decirse que la norma bajo estudio incorpora de facto un nuevo peligro procesal -o, al menos, una nueva valoración de éstos-: el de no arrepentirse y no colaborar con la investigación [...] tanto la amenaza de prisión preventiva inmediata para aquel imputado que llega en libertad a declarar, o bien la continuidad de la detención cautelar para aquel que ya se encuentra detenido preventivamente, operando como "incentivo" para acogerse a la figura del arrepentido, y en tales condiciones en última instancia en manos del juzgador, constituye una compulsión moral sobre la voluntad del imputado, una coerción inaceptable, que se encuentra reñida con la vigencia de las garantías constitucionales de prohibición de autoincriminación, presunción de inocencia y la ética que nunca debe abandonar el Estado de Derecho. ${ }^{21}$

\section{En función de ello, Figueroa consideró que}

... más allá de los presuntos abusos de poder denunciados, lo cierto es que la ilegítima vinculación del acogimiento a la figura del arrepentido por parte de un imputado y el impacto directo en su libertad o prisión cautelar, encuentra anclaje en las previsiones de la ley -concretamente su art. $4^{\circ}-$, por lo que es ésta misma -y no su eventual aplicación coyuntural en un caso concreto- la que resulta contraria a la vigencia de las garantías constitucionales de prohibición de autoincriminación y presunción de inocencia. ${ }^{22}$

\section{En la misma línea argumental, Luis H. Alén (2018) sostiene:}

... la figura del arrepentido supone que este sufre un contenido coactivo para que reconozca algún ilícito para recibir un beneficio. Es decir que, contrariamente a la protección constitucional de que goza todo imputado de no estar obligado a declarar contra sí mismo, se vulnera su voluntad cuando se le manifiesta [...] que si no colabora puede olvidarse de recuperar su libertad. (p. 67)

Por otro lado, un grupo doctrinal ${ }^{23}$ utiliza un tercer argumento relativo a la violación de la prohibición de autoincriminación forzada, consistente en la incorporación del artículo 276 bis del Código Penal, es decir, al delito de suministro malicioso de información falsa o inexacta por parte del imputado colaborador. A este respecto, Figueroa considera que

21 Cámara Federal de Casación Penal, Sala I: De Vido, Julio Miguel y otros s/recurso de casación, apartado 2.3.d. del voto de Ana María Figueroa.

22 Ídem.

23 Además de los citados, véanse Abou Assali y Romero Villanueva (2019), Bernardini y Nicolás (2020) y Minoggio (2019). 
... la tipificación de la conducta del imputado que, acogiéndose a la figura del arrepentido, negociando su libertad, aporta información no veraz, resulta violatoria de la garantía de prohibición de la autoincriminación, además que desdecirse implica el riesgo de perder los beneficios y ser imputado por otro delito, aunque tampoco pudiera descartarse otra situación de necesidad fundante de una exclusión del injusto penal. Ello trastoca la naturaleza de la declaración del imputado, quien, por vigencia de la garantía referida, no depone bajo juramento de decir verdad, pudiendo en nuestro orden interno incluso mentir en sus expresiones, sin que ello tenga un correlato negativo para su situación procesal. ${ }^{24}$

Finalmente, Gustavo Aboso (2017), haciendo referencia a la posibilidad de la exigencia de una promesa o juramento de decir verdad, dice:

La naturaleza confusa de la calidad del arrepentido, que aporta información de modo voluntario a cambio de un mejor tratamiento punitivo, pero que no alcanza para asumir la calidad de testigo y tampoco los deberes que pesan sobre este, determina que su declaración testimonial no debe ser exteriorizada bajo juramento o promesa de decir la verdad. Si el arrepentido declarase como testigo hábil y se le impusiesen los deberes de decir la verdad, ese testimonio puede ser tachado de inválido, ya que el elemento volitivo estaría seriamente condicionado por ese deber de decir la verdad, en consecuencia, corresponderá analizar en el caso concreto si ese deber impuesto de decir la verdad pudo condicionar o no su declaración, en especial, si ella fue autoincriminante debe declararse su nulidad, ya que ello afectaría la garantía del nemo tenetur. (s.p.)

\subsubsection{La garantía contra la autoincriminación forzada en la jurisprudencia de la Corte Suprema de Justicia de la Nación y la Suprema Corte de los Estados Unidos}

Sentado ello, considero que la interpretación de la garantía de la prohibición de la autoincriminación forzada realizada por quienes critican el instituto del imputado colaborador es errónea y frecuentemente se apoya en citas de jurisprudencia de la Corte Suprema de Justicia de la Nación que, ante un examen detallado, claramente no resulta aplicable.

En este sentido, primeramente debe resaltarse que nuestro máximo tribunal ha considerado violada dicha garantía en casos de absolución de posiciones bajo juramento en los que el imputado no podía negarse a declarar; ${ }^{25}$ en una

24 Cámara Federal de Casación Penal, Sala I: De Vido, Julio Miguel y otros s/recurso de casación, apartado 2.3.d. del voto de Ana María Figueroa.

25 Corte Suprema de Justicia de la Nación, Eduardo Mendoza, por falsificación de un manifiesto de Aduana, 
declaración en la que se había citado al imputado sin expresarle la causa de su convocatoria, tomándosele juramento con anterioridad a darle a conocer que estaba imputado y sin advertirle del derecho a designar un defensor y a aportar prueba de descargo $;^{26}$ en el caso de un imputado citado como testigo obligado a declarar bajo juramento; ${ }^{27}$ casos de valoración negativa por parte del juez de una declaración negando el hecho atribuido; ${ }^{28}$ y casos de confesiones o datos extraídos en sede policial por ser fruto de violencia física o coacción. ${ }^{29}$

Es decir, en todos estos casos en los que la Corte Suprema hizo valer la garantía de la prohibición de la autoincriminación forzada, se trató de imputados obligados a declarar, sea por imperio de la ley, sea por intromisiones indebidas de funcionarios públicos. En todo caso, solo las primeras podrían llegar a ser susceptibles de una declaración de inconstitucionalidad -al menos en el caso concreto-, mientras que las segundas son casos de nulidades o impugnación de los actos procesales.

Es que, en definitiva -y así lo entendió la Corte Suprema-, lo prohibido por la Constitución Nacional es compeler física o moralmente a una persona con el fin de obtener comunicaciones o expresiones que debieran provenir de su libre voluntad, pero no incluye los casos en los que la evidencia es de índole material $^{30}$ o es producto de la libre voluntad del imputado. ${ }^{31}$

Por su parte, resulta relevante destacar la doctrina sobre la materia de la Suprema Corte de los Estados Unidos, ya que trató con mayor profundidad la cuestión específica de la garantía contra la autoincriminación forzada en institutos similares al del imputado arrepentido. Ello resulta pertinente en razón de la influencia que ejercen en nuestra jurisprudencia y la similitud entre nuestra norma constitucional con la enmienda $\mathrm{V}$ de la Constitución de los Estados Unidos de 1787 -fuente de nuestra Constitución Nacional-, en tanto prevé

28/10/1864, Fallos: 1:350.

26 Corte Suprema de Justicia de la Nación, El Atlántico diario s/infracción art. 23, ley 4664 -Mar del Plata-, 22/11/1971, Fallos: 281:177.

27 Corte Suprema de Justicia de la Nación, Raisberg de Merenzon, Claudia Ethel s/suspensión, 04/05/1995, Fallos: 318:963.

28 Corte Suprema de Justicia de la Nación, Casas Alejandro Esteban s/Homicidio Culposo, 03/05/2007, Fallos: 330:1975, que se remite al dictamen del Procurador General de la Nación.

29 Corte Suprema de Justicia de la Nación, Montenegro, Luciano Bernardino, 10/12/1981, Fallos: 303:1938; y Ruiz, Roque A. s/hurtos reiterados, 17/09/1987, Fallos: 310:1847.

30 Corte Suprema de Justicia de la Nación, Juan José Cincotta, 13/02/1963, Fallos: 255:18.

31 Corte Suprema de Justicia de la Nación, Zambrana Daza, Norma Beatriz s/Infracción a la Ley 23737, 12/08/1997, Fallos: 320:1717. 
que ninguna persona será "compelida en un caso criminal a ser testigo contra sí mismo”.

Este tribunal estadounidense ha sostenido -en un caso en el que el imputado detenido y sin abogado confesó el delito- que la confesión, para no violar la garantía contra la autoincriminación forzada, debe ser "libre y voluntaria: esto es, no debe ser extraída mediante ninguna suerte de amenazas o violencia, ni obtenida mediante promesas directas o implícitas, por ligeras que sean, ni mediante el ejercicio de cualquier influencia impropia [...] En otras palabras, la persona no debe haber sido compelida a autoincriminarse", 32 teniendo el imputado la "libre elección de admitir, negar, o rehusarse a contestar" . 33 Además, ha sostenido que las enmiendas $\mathrm{V}$ y XIV 34 "prohíben a los estados recurrir al encarcelamiento, como en el caso, para compelerlo [al imputado] a contestar preguntas que pudieran incriminarlo" de modo tal que protegen "... el derecho de la persona a permanecer en silencio a menos que elija hablar en el ilimitado ejercicio de su libre voluntad, y a no sufrir pena alguna [...] por tal silencio". 35

Asimismo, en el célebre fallo Miranda $v$. Arizona ${ }^{36}$ se ha considerado violatoria de la mencionada garantía la declaración del imputado detenido si previamente no se le advirtieron sus derechos, entre los cuales se encuentra el de negarse a declarar y a tener un abogado defensor. Esta advertencia de los derechos del imputado tiene por doble finalidad la de proteger la capacidad del sospechoso de tomar decisiones de manera autónoma y la de garantizar la confiabilidad de la confesión (Joselow, 2019).

Por otro lado, y respecto a los beneficios que se obtienen con la confesión o el plea bargain (negociación de la declaración de culpabilidad), el máximo tribunal estadounidense consideró que no se viola la prohibición de la autoincriminación forzada cuando la confesión se encuentra motivada por el deseo

32 Suprema Corte de los Estados Unidos, Bram v. US, 13/12/1897, 168 U.S. 532. Véase también respecto a la aplicación de la garantía a los estados, Suprema Corte de los Estados Unidos, Malloy v. Hogan, 05/06/1966, 378 U.S. 1. Todas las sentencias citadas de este tribunal se encuentran disponibles en el sitio oficial de la Biblioteca del Congreso de los Estado Unidos: https://www.loc.gov/. Las traducciones son propias.

33 Suprema Corte de los Estados Unidos, Lisenba v. California, 08/12/1941, 314 U.S. 219.

34 Enmienda XIV de la Constitución de los Estados Unidos, Sección 1: “[...] Ningún estado podrá dictar ni dar efecto a cualquier ley que limite los privilegios o inmunidades de los ciudadanos de los Estados Unidos; ni tampoco podrá estado alguno privar a cualquier persona de la vida, la libertad o la propiedad sin el debido proceso legal; ni negar a cualquier persona que se encuentre dentro de su jurisdicción la protección de las leyes por igual”.

35 Suprema Corte de los Estados Unidos, Malloy v. Hogan, 15/06/1966, 378 U.S. 1.

36 Suprema Corte de los Estados Unidos, Miranda v. Arizona, 13/06/1966, 384 U.S. 436. 
del imputado -asistido por su defensor- de aceptar la certeza o probabilidad de una pena menor, en vez de enfrentarse a un mayor número de posibilidades que van desde la absolución hasta la condena a una pena mayor que esté prevista por la ley para el delito imputado. Considerar que esas confesiones implican una autoincriminación forzada

requeriría [...] que se prohíba la declaración de culpabilidad por completo, que deba preverse una pena única invariable para cada delito previsto por las leyes, o colocar la función de determinar la pena en una autoridad distinta que no conozca el modo en que se logró una condena. A todo evento, sería necesario prohibir a los fiscales y jueces que acepten declaraciones de culpabilidad para delitos específicos, a infracciones menores, o a cargos reducidos. La Quinta Enmienda no llega tan lejos. ${ }^{37}$

Para este tribunal, una confesión de culpabilidad realizada por una

persona completamente consciente de las consecuencias directas, incluyendo el valor actual de todos los compromisos hechos para con él por la corte, el fiscal, o su propio defensor, deben ser declarados válidos a menos que sean inducidos por amenazas (o promesas de cesar con un acoso indebido), una malinterpretación (incluyendo promesas incumplidas o incumplibles), o quizás por promesas que son por su naturaleza impropias por no tener relación con la incumbencia del fiscal (por ejemplo, sobornos). ${ }^{38}$

Es decir, para la máxima corte estadounidense, la garantía contra la autoincriminación forzada se encuentra resguardada siempre que se cumpla con la "regla de la voluntariedad en la autoincriminación" (Godsey, 2005), lo que resulta perfectamente compatible con los incentivos relativos a las reducciones de pena.

En suma, y volviendo a la doctrina nacional, tal como se desprende de la recta interpretación de la jurisprudencia y del texto mismo de las cláusulas constitucionales y convencionales que consagran la garantía, como explicaba Badeni (2006), nuestra garantía de la prohibición contra la autoincriminación forzada significa que

... 1) una persona puede prestar declaración voluntariamente, y tendrá que atenerse a las consecuencias de sus manifestaciones o confesión; 2) ninguna persona puede ser obligada a prestar declaración en calidad de imputada o procesada cuando se le

37 Suprema Corte de los Estados Unidos, Brady v. United States, 04/05/1970, 397 U.S. 742.

38 Ídem. 
achaca la comisión de un hecho delictivo; 3) si una persona se allana a prestar declaración voluntariamente, puede abstenerse de declarar respecto de aquellos hechos, datos o circunstancias que se traduzcan en una autoincriminación; 4) la negativa a declarar no puede generar una presunción en contra de sus derechos. (p. 1151)

\subsubsection{Sobre los beneficios de la Ley 27304 y la libertad en la declaración}

Entonces, la cuestión es si la Ley 27304 prevé un instituto que en su aplicación logre compeler de manera general a los imputados a autoincriminarse, y la respuesta es negativa. El artículo 41 ter del Código Penal no requiere ni exige que el imputado colaborador deba autoincriminarse, sino que prevé una propuesta, una oferta que el imputado puede aceptar o rechazar sin que ello implique un perjuicio o presunción en su contra.

La ley establece que los imputados puedan acogerse al instituto del imputado colaborador, cumpliendo con las condiciones pertinentes, a cambio de un beneficio de reducción de la escala penal. Quien elige acogerse al instituto lo deberá hacer como fruto de una decisión libre, resguardándose esa libertad mediante la intervención obligatoria del abogado defensor y del juez, lo que hace al instituto compatible un instrumento válido de la política criminal del Estado. ${ }^{39}$

Como bien resalta el juez Diego Barroetaveña en su voto en De Vido, la garantía de la prohibición de la autoincriminación forzada se resguarda mediante las formalidades que tienden a asegurar la voluntariedad de la declaración:

... estamos ante un instituto claramente reglado en el que el imputado, con conocimiento acabado del hecho que se le atribuye, asistencia letrada y en pleno ejercicio de sus derechos -entre el que se encuentra callar- decide declarar y aportar información útil a la investigación que lo involucra a él y a otras personas, las que necesariamente deben tener una responsabilidad igual o mayor a la de aquél. Además, la misma ley prevé los mecanismos para asegurar y verificar la voluntariedad de la declaración, no sólo por la presencia y asesoramiento de un defensor para celebrar el acuerdo de colaboración, sino porque el pacto arribado entre el imputado y el fiscal debe presentarse al juez para su homologación y en la audiencia que prevé el art. 10 [de la Ley 27304]. ${ }^{40}$

Frente a la crítica referida a que el beneficio de reducción de la escala penal

39 En el mismo sentido sobre la Ley 25742, Báez (2003).

40 Cámara Federal de Casación Penal, Sala I: De Vido, Julio Miguel y otros s/recurso de casación, voto de 
implica un agravamiento de la pena para quien no confiesa, una adecuada respuesta es la brindada por Norberto Spolansky (2001), quien ha sostenido que

[c]uando se ofrece al posible arrepentido la opción de decir lo que sabe -y lo que sabe es útil y eficaz para descubrir el hecho delictivo e identificar a los responsables- a cambio de una pena más leve, no se está planteando una alternativa en la que la modalidad más grave es un hecho prohibido (la tortura), sino la manera de mostrarle que puede tener un tratamiento más benévolo, basado en un criterio puramente utilitario si aporta datos útiles y eficaces para descubrir el hecho delictivo e identificar a los responsables del hecho. (s.p.)

Así entonces, coincidiendo con Cafferata Nores (2018),

[l]a prohibición constitucional consiste en que nadie puede ser obligado a declarar en su contra. En este caso, el arrepentido no es obligado por ninguna autoridad a declarar en su contra. Lo hace voluntariamente, solo procurando aminorar su responsabilidad penal. (p. 5) ${ }^{41}$

Del beneficio no se sigue una compulsión a autoincriminarse, porque el no acogimiento al instituto no implica una amenaza de una pena mayor en castigo al ejercicio del derecho a negarse a declarar. Primeramente, la afirmación contraria es empíricamente incorrecta, en tanto no se aumentaron las escalas penales de los delitos a los que es aplicable el instituto, sino que se previó solamente esta reducción como un premio a la delación. Asimismo, tampoco se da el caso en el que las escalas penales previstas para los delitos a los que es aplicable la Ley 27304 sean exageradamente elevadas y desproporcionadas respecto a la culpabilidad, ${ }^{42}$ de modo tal que la aplicación de la pena ordinariamente legislada viole el principio de proporcionalidad o la prohibición de imponer castigos crueles, inhumanos o degradantes, ${ }^{43}$ mientras que el beneficio de la ley logra evadir ese castigo arbitrario.

Además, aquel razonamiento crítico del beneficio parece partir del presu-

Diego G. Barroetaveña, apartado III.b.2.

41 Seguido por Llera (2019a).

42 Sobre este punto, véase Uriburu (2019).

43 Principio receptado por el artículo 18 de la Constitución Nacional y los siguientes instrumentos internacionales con jerarquía constitucional: artículo 5 de la Declaración Universal de Derechos Humanos; artículo XXVI de la Declaración Americana de Derechos y Deberes del Hombre; artículo 5.1 de la Convención Americana de Derechos Humanos; artículos 7 y 10 del Pacto Internacional de Derechos Civiles y Políticos; artículo 37 de la Convención sobre los Derechos del Niño; artículo 15.1 de la Convención sobre los Derechos de las Personas con Discapacidad; y artículo 16.1 de la 
puesto de que al imputado siempre le va a caber una pena, cuando en realidad solamente debería aplicarse una pena cuando haya certeza objetiva de culpabilidad fundada en elementos probatorios lícitamente reunidos en el marco del proceso penal. De ello se sigue que un imputado inocente siempre podrá rechazar este beneficio y probar su inocencia en juicio y en los procedimientos recursivos previstos.

Si bien sería ingenuo creer que el funcionamiento de la administración de justicia federal y local en nuestro país es perfecto -y dista muchísimo de ello-, también lo sería legislar pensando en que estos sistemas son puramente arbitrarios y que todos los funcionarios actuarán mal y con una selectividad discriminatoria. Se debe legislar pensando tanto en el buen juez como en el mal juez. Respecto al primero, previendo reglas justas y eficaces para que pueda "administrar justicia bien y legalmente, y en conformidad a lo que prescribe la Constitución”, ${ }^{44}$ mientras que respecto al segundo deberán preverse garantías y controles republicanos para evitar su mal desempeño, principalmente las garantías de la Constitución.

En este punto, la Ley 27304 no afecta garantía alguna, porque no legisla un castigo para el imputado que elige no declarar de manera de sancionar su silencio y compelerlo a declarar. Al contrario, se enmarca perfectamente en el ámbito de discreción del legislador, habilitado por la Constitución en tanto representantes del pueblo que ejercen la prudencia política, y, como tal, es una cuestión política no justiciable y ajena al control de los jueces, más allá de las preferencias personales sobre su acierto o desacierto.

Por otro lado, respecto a la supuesta presión psicológica que implica tener que decidir entre arriesgarse a una pena mayor en un juicio o autoincriminarse y recibir una pena menor, debe decirse que los condicionamientos o presiones psicológicas también son susceptibles de discriminación entre presiones legítimas e ilegítimas. Por ejemplo, en el caso de un comodato, el hecho de que el propietario pida al vencimiento del plazo que se le restituya la cosa bajo apercibimiento de iniciar acciones legales y cobrar las costas no es un caso de una presión ilegítima. Amenazar con la aplicación lisa y llana del derecho no es una presión ilegítima ${ }^{45} \mathrm{y}$, por lo tanto, jamás puede erigirse en un tipo de amenaza considerada como coacción susceptible de alterar el estado de liber-

Convención contra la Tortura y Otros Tratos o Penas Crueles, Inhumanos o Degradantes.

44 Constitución de la Nación Argentina, artículo 112.

45 En similar sentido, respecto al delito de amenazas del artículo 149 bis del Código Penal, aunque no sea una exigencia de la letra de la ley, la doctrina ha entendido que esta debe ser "injusta", es decir que el 
tad del imputado que decide declarar. Una recta concepción de la libertad no aceptaría jamás a la amenaza del derecho como limitante real de la voluntariedad de los actos, al contrario, sería un presupuesto del acto voluntario conocer las implicancias legales de su desarrollo u omisión.

En suma, "la garantía constitucional contra la autoincriminación está dirigida contra los abusos de otras personas y no contra la acción de la naturaleza, las autoagresiones o incluso la fuerza ejercida dentro de la ley por los funcionarios encargados de hacerla cumplir" ${ }^{46}$ En caso de ejercicio de presiones ilegítimas, lo que habrá es una nulidad por abuso de un instituto legal, pero nunca se causará la inconstitucionalidad de la norma en sí que, rectamente interpretada y aplicada, se adecua perfectamente a los postulados del derecho constitucional local y al derecho internacional de los derechos humanos.

\subsubsection{La libertad durante el proceso y la libertad en la declaración como imputado colaborador}

Quizá las críticas más fuertes relativas a la violación de la garantía contra la autoincriminación forzada por parte de la Ley 27304 sean las referentes al uso de la libertad durante el proceso como moneda de cambio para compeler a los imputados a declarar en su contra y de sus posibles cómplices.

Ciertamente, si se demostrase en un caso concreto que un juez ha amenazado ilegítimamente a un imputado con dictarle o mantenerlo en prisión preventiva a menos que declare como imputado colaborador, dicha declaración sería nula por estar viciada su voluntad por coacción moral. Es más, considero que dicha conducta con fin investigativo podría ser equiparable a la tortura en los términos del artículo 2 de la Convención Interamericana para Prevenir y Sancionar la Tortura y el artículo 1 de la Convención contra la Tortura y Otros Tratos o Penas Crueles, Inhumanos o Degradantes. Pero justamente esta circunstancia no deja de ser una cuestión que en todo caso deberá discutirse en el marco de una nulidad o impugnación de los actos procesales, ya que en nada se relaciona el abuso del instituto por parte de un mal juez o fiscal con la inconstitucionalidad de la norma.

Ahora bien, resultaría discutible la constitucionalidad de la ley si el acogi-

autor no tenga derecho a ocasionarla, por lo que no es una amenaza el anuncio del legítimo ejercicio de un derecho. Véase, por ejemplo, Creus y Buompadre (2013, p. 360) y D'Alessio (2004, p. 342).

46 Corte Suprema de Justicia de la Nación, Baldivieso, César Alejandro s/causa n 4733, 20/04/2010, Fallos: 333:405, voto de Carmen Argibay. 
miento al instituto del imputado colaborador conllevara automáticamente la liberación del arrepentido, pero esta premisa es una derivación de una interpretación equivocada de su texto. Se reitera que el artículo 4 de la Ley 27304 prevé que:

Cuando la reducción de la escala penal prevista por el artículo 41 ter del Código Penal aparezca como probable, podrá ser considerada a los fines de la excarcelación o de la exención de prisión, de acuerdo a las normas procesales comunes.

Partiendo desde una interpretación sistemática del conjunto de las normas que regulan la prisión preventiva, es fundamental destacar que este artículo resulta superabundante, es decir, podría no estar y en nada cambiaría el sistema jurídico de la prisión preventiva. Es una de esas normas que funcionan como mera clarificación, no infrecuente en nuestra técnica legislativa, ${ }^{47}$ y ello se desprende inequívocamente de su referencia a las "normas procesales comunes". Si se consagrara una excepción a las normas comunes -léase, los códigos procesales penales aplicables-, no tendría sentido hacer esta referencia.

Por eso disiento con las posturas que sostienen que, al efecto de la evaluación de una medida coercitiva restrictiva de la libertad durante el proceso, hay un "impacto directo" entre la realización del acuerdo de colaboración y la libertad durante el proceso, o que la ley cree como riesgo procesal el "no arrepentimiento", o que "debe ser sopesada, a su vez, la utilidad y eficacia que brinda la información que aporte el/la colaborador/a arrepentido/a” (Sebastián, 2018). Ello, por cuanto la norma no premia realización del acuerdo o la veracidad y utilidad de la información brindada en sí misma, sino que manda al juez a evaluar si dicha información veraz logra modificar, reducir o eliminar el riesgo procesal que haga pertinente el dictado de la excarcelación, de conformidad con las normas procesales comunes.

Entonces, la referencia a la consideración del acuerdo de colaboración a los efectos de la prisión preventiva provoca que el juez deba evaluar si esta actitud del imputado colaborador afecta o no la subsistencia de los riesgos procesales. Justamente, estos riesgo procesales, siguiendo la doctrina tradicional que sobrevino de manera casi uniforme tras el dictado del fallo plenario Díaz Bessone, ${ }^{48}$ son actualmente los únicos motivos válidos conforme a nuestra legislación fe-

47 Por ejemplo, la primera parte del artículo 1 del Código Civil y Comercial y el artículo 1 del Código Procesal Penal Federal.

48 Cámara Nacional de Casación Penal, Diaz Bessone, Ramón Gerardo s/Recurso de inaplicabilidad de ley, 
dera ${ }^{49}$ y a la jurisprudencia internaciona ${ }^{50}$ para restringir la libertad del imputado sin condena durante el proceso.

Esta variación en el riesgo procesal se valorará según las reglas de la experiencia y, particularmente, según los indicadores enumerados por los artículos 221 y 222 del Código Procesal Penal Federal, relativos al riesgo de fuga y de entorpecimiento de la investigación, respectivamente. Resulta patente que si la escala penal prevista para un delito es un indicador del riesgo de fuga en tanto pena en expectativa cuando una condena parezca probable, la alta probabilidad de la reducción de esta escala penal por el acuerdo de colaboración disminuye o neutraliza este riesgo. Ello cobra aún más fuerza si a raíz de este beneficio la pena puede ser dejada en suspenso, por lo que el imputado no iría a prisión en caso de ser condenado. Además, un imputado que colabora con la investigación, y que en definitiva se vio beneficiado por un instituto como el comentado, tiene menos incentivos para entorpecer la investigación, ${ }^{51}$ de hecho, la ayuda.

No obstante, de ninguna manera es automática la neutralización de los riesgos procesales con la celebración del acuerdo de colaboración. Es decir, no es un "beneficio inmediato", ya que puede suceder que de todas formas subsistan riesgos procesales que impliquen que el imputado deba ser sometido a prisión preventiva. Más aún, podría suceder que el contenido de la declaración todavía no haya podido ser mínimamente corroborado, en cuyo caso, a pesar de haber declarado amparado en la calidad de imputado colaborador, de momento la procedencia del beneficio no puede ser juzgada como probable. La mera declaración del imputado colaborador por sí sola no tiene entidad alguna para conducir a los beneficios otorgados por la Ley 27304, sino que ello dependerá de la corroboración mediante elementos probatorios distintos. ${ }^{52}$

Paralelamente, los críticos de este instituto parecerían dejar de lado la existencia de un contraincentivo a la falsa declaración del imputado al efecto de lograr la libertad durante el proceso. Es que si el imputado maliciosamente proporciona datos falsos o inexactos en su declaración como arrepentido, a la

30/10/2008, Plenario N 13, Acuerdo nro. 1/08.

49 Zanjándose a nivel legislativo la cuestión al implementarse los artículos 210, 221 y 222 del Código Procesal Penal Federal mediante la Resolución 2/2019 de la Comisión Bicameral de Monitoreo e Implementación del Código Procesal Penal Federal.

50 V.gr., recientemente, Corte Interamericana de Derechos Humanos, Romero Feris vs. Argentina, Fondo, Reparaciones y Costas, 15/10/2018; y Corte Interamericana de Derechos Humanos, Jenkins vs. Argentina, Excepciones Preliminares, Fondo, Reparaciones y Costas, 26/11/2019.

51 En igual sentido opinan Charni y Frezzini (2019).

52 En el mismo sentido, Frezzini (2020). 
eventual pena que le corresponde por el delito por el cual se lo investigó originalmente se le sumará la pena fijada para el delito previsto por el artículo 276 bis del Código Penal.

Entonces, toda vez que el instituto del imputado colaborador no afecte las reglas generales del mantenimiento y la restricción de la libertad durante el proceso, bajo ningún punto de vista puede generar en sí un condicionamiento a la voluntad del imputado de modo tal que se encuentre compelido a autoincriminarse.

Más dificultoso resulta el caso en el que un fiscal negocie con el imputado la libertad durante el proceso a cambio de celebrar un acuerdo de colaboración. Ello está permitido donde rige el sistema acusatorio, por cuanto es el acusador el único facultado para pedir las medidas de coerción durante el proceso, no pudiéndolas dictar el juez de oficio. Pero siempre que la privación de la libertad se encuentre estrictamente ajustada a derecho y no se trate de un encarcelamiento arbitrario, ello no debería ser considerado un obstáculo a la libertad del imputado, puesto que esa negociación siempre será lícita, como la es la del juicio abreviado (Pérez Arias, 2006).

Los miembros de una sociedad deben soportar las cargas que lícitamente implican ser parte de ella, y una de las más gravosas es la de ser privado de la libertad sin condena cuando concurran riesgos procesales que no puedan ser salvados de otra forma. Por ende, así como no se puede ejercer la legítima defensa contra un funcionario público que cumple una orden de detención equivocada, pero legítimamente dictada, tampoco es lícito en un Estado de derecho recurrir a un delito -suministrar maliciosamente información falsa o inexacta del artículo 276 bis del Código Penal- para eludir las consecuencias negativas de un acto legítimo, aunque equivocado. A todo evento, lo que debe extremarse es el cumplimiento de la ley y los controles rápidos y eficaces sobre la recta aplicación de la prisión preventiva mediante los procedimientos recursivos.

\subsubsection{El reconocimiento de participación y el delito del artículo 276 bis del Código Penal}

Por último, con relación a la crítica referida a la creación del delito de suministro malicioso de información falsa o inexacta del imputado colaborador, a mi criterio no le resulta aplicable en modo alguno la jurisprudencia de la Corte Suprema relativa a la violación de la garantía contra la autoincriminación forzada. Es que, a diferencia del testigo o de la antigua absolución de posiciones en el proceso penal, ninguna norma de la Ley 27304 obliga al imputado a declarar 
como arrepentido. Se reitera: es una oferta que deberá debidamente ponderar y elegir aceptar o rechazar. No es el juez quien obliga al imputado a declarar, es el imputado quien se acerca y decide voluntariamente hacerlo en miras a un mejoramiento de su situación frente a una probable sanción y, de negarse, ningún perjuicio le debe acarrear tal decisión.

De la misma manera, tampoco es violatoria de la garantía analizada la condena fundada en el reconocimiento de la participación en el ilícito penal-como sucede en el juicio abreviado-, ${ }^{53}$ ya que no existe un derecho a "no incriminarse" por el cual esté vedada la exigencia, en el marco de un instituto voluntario, de reconocer la culpabilidad. ${ }^{54}$ Es más, para el imputado que al reconocer la culpabilidad obtiene un beneficio, oponerle dicha garantía para anular este reconocimiento transformaría su derecho a no autoincriminarse en una obligación insalvable de la cual no podría disponer y que lo puede perjudicar.

Sin perjuicio de ello, a modo de digresión, a mi criterio en el sistema de la Ley 27304 -no así en el sistema de los artículos 195 y subsiguientes del Código Procesal Penal Federal- el imputado que mantiene su inocencia también es libre de acogerse o no al instituto, interpretando en sentido amplio la norma en tanto prevé que el objeto de la declaración sean "hechos ilícitos de los que haya sido partícipe”. Este sería el caso de quienes hayan intervenido en el curso causal mediante actos cotidianos o neutros que no implican participación criminal en el sentido de los artículos 45 y 46 del Código Penal, o de quienes hayan intervenido antijurídicamente en un hecho ilícito sin ser culpables o sin ser punibles. Como corolario, cabe aclarar que incluso de darse el caso de que un imputado no culpable reconociera responsabilidad criminal, es deber del Ministerio Público Fiscal no solicitar pena y del Poder Judicial no condenarlo, lo que no debería tener implicancias de responsabilidad criminal, sin perjuicio de la posible violación al artículo 276 bis del Código Penal.

Por otro lado, el hecho de que, fruto de nuestra evolución jurídica a lo largo de la historia, nuestro ordenamiento nacional y federal actual permita que el imputado mienta en su declaración indagatoria o en juicio para no restringir su derecho de defensa -en tanto no se prevé ninguna sanción para ello-, no implica que tenga un derecho constitucional a mentir en el proceso, ni mucho menos que exista un pretendido derecho a "no incriminarse" ${ }^{55}$ No existe un

53 Artículo 431 bis del Código Procesal Penal de la Nación y artículo 323 del Código Procesal Penal Federal.

54 La existencia del derecho a no autoincriminarse es planteado, por ejemplo, por Gustavo Ariel Fernández (2016).

55 Carrió (1994, pp. 278-279) resalta la existencia de una -errada- corriente jurisprudencial que sostie- 
derecho del imputado a mentir, ${ }^{56} \mathrm{ni}$ en el derecho positivo interno ni en el derecho internacional, así como tampoco es un derecho que surja del derecho natural ni que sea un derecho no enumerado que emane del principio de la soberanía del pueblo y de la forma republicana de gobierno del artículo 33 de la Constitución Nacional.

Lo contrario implicaría herir gravemente al instituto del imputado colaborador, por cuanto se permitiría, sin ningún fundamento normativo, que un imputado mendaz maliciosamente distraiga la investigación hacia el rumbo equivocado y sin consecuencias. Ello desnaturalizaría la esencia del instituto, que es darle un beneficio al imputado para obtener información confiable y corroborable que permita avanzar en la investigación, en la que se invierten recursos del Estado. La impunidad general de la mentira en el proceso no alcanza ni ampara las manifestaciones que efectúe el imputado colaborador, "pues allí no estará ejerciendo su derecho de defensa, sino que, pretendiendo obtener beneficio, estará brindando información a sabiendas de que esta debe contribuir con una investigación" (Ferrer, 2018, p. 54).

En definitiva, otorgarle impunemente la posibilidad de desdecirse al imputado colaborador no solo no se desprende de una aplicación de la garantía contra la autoincriminación forzada ni es una exigencia de un Estado de derecho, sino que contraría la razón de ser misma de una declaración voluntaria a cambio de un beneficio como el de la Ley 27304.

\subsubsection{Consideraciones finales sobre la garantía contra la autoincriminación forzada}

Una concepción de la libertad de la voluntad en la que cualquier condicionamiento, por más leve o potencial que sea, implique una coacción, en realidad importa una desnaturalización del concepto mismo de "libre albedrío". Ciertamente, la libertad rara vez es plena porque los actos humanos no se ejercen en el abstracto, sino que están sujetos a las condiciones del entorno. Pero estas circunstancias, en tanto no eliminen la aptitud genérica de actuar de la persona (las tradicionales fuerza física irresistible, estado de inconsciencia y movimientos reflejos), no distorsionen el discernimiento (ignorancia, error, engaño) o no la condicionen gravemente (como el miedo y la coacción moral), no eliminan la voluntariedad del acto, puesto que el hombre no es un animal determinado

ne que los testigos tienen derecho a mentir bajo juramento con el fin de no autoincriminarse.

En el mismo sentido opinan Hairabedián (2016) y Llera (2019b). 
por los impulsos, sino que con su inteligencia y libertad es capaz de dirigir su voluntad hacia los fines que escoja.

La libre voluntad y la responsabilidad por las consecuencias son las dos caras de la misma moneda de la naturaleza del comportamiento humano. Este binomio es un presupuesto básico de la moral, que sienta las bases mismas del derecho y de la posibilidad de coexistencia en una sociedad. Invocar la inexistencia de la libertad es decir que la persona no es responsable de la bondad o malicia de sus actos, y negar la responsabilidad por las consecuencias es negar la personalidad de quien ejerce la voluntad porque sus actos no le serían imputables. De ahí que no debe ligeramente alegarse la inexistencia de voluntad por cualquier causa que limite la voluntariedad de los actos, ya que tal idea termina por alterar el concepto de "persona" y torna imposible la existencia del derecho, conduciendo a la disolución de la sociedad.

En definitiva, ni el beneficio que la ley otorga al imputado colaborador, ni la probabilidad del otorgamiento de la libertad durante el proceso ni el castigo a la mentira en dicha declaración son en sí mismos condicionamientos ilegítimos que atenten contra la libertad de manera que impliquen una obligación o compulsión a la autoincriminación, eliminando la voluntariedad de la declaración. $\mathrm{El}$ acogimiento al instituto es una decisión que, tomada junto con su defensor y resguardada su libertad por el juez en la audiencia prevista a tal efecto, está normativamente prevista para ejercerse en plena libertad real, sin violencia o coacción. El imputado solamente deberá soportar las legítimas consecuencias que emanen de su decisión, conforme elija aceptar o rechazar la celebración del acuerdo.

\subsection{Principio de igualdad ante la ley}

\subsubsection{Críticas a la constitucionalidad del instituto}

En otro orden argumental, corresponde adentrarse en las críticas esbozadas contra la Ley 27304 relativas a una presunta violación al principio constitucional de igualdad ante la ley.

Analizando un proyecto de ley anterior relativo a la figura del arrepentido, Terragni (1998) sostuvo que la figura del arrepentido

... agravia el principio de igualdad ante la ley, ya que ésta se dicta [...] para regir erga omnes y sin embargo esta norma posibilitaría una reacción estatal distinta, no obstante que los hechos que se juzgan fueron cometidos por hombre semejantes, a los que sin embargo se los trata de manera distinta. También atenta contra el 
principio de igualdad ante la ley pues beneficia al que primero "colabora", pues cuando los demás se decidan a hacerlo es posible que la "cooperación” de ellos ya no sea necesaria. (s.p.)

\section{En la misma línea crítica, Sancinetti (2016) entiende que}

... bien podría ocurrir que un partícipe de muy escaso poder en la organización no tenga los conocimientos "interesantes” para el Ministerio Público que sí pudiera tener otro sujeto de "mayor envergadura" en la asociación ilícita. Éste, a pesar de su eventual mayor ilícito y culpabilidad, podría tener informaciones, que entregase a cambio de obtener la "rebaja de ocasión" por parte de la fiscalía y de los tribunales, de las que, en cambio, no dispusiera otro sujeto, cuya participación implicara un menor ilícito y culpabilidad en el hecho o hechos implicados. Entonces, ése último podría ser penado más gravemente que el otro "por no disponer de informaciones", lo cual altera el principio de igualdad, pues el principio de igualdad se traduce, en el derecho penal, en que cada uno responda según su contenido de ilícito y culpabilidad. (p. 9)

En un segundo orden de ideas, agrega Sancinetti (2016) que el instituto del imputado colaborador admite la arbitrariedad en la persecución penal, ya que

... el gran campo de manipulabilidad que abren instituciones de esta índole permitiría que se le colgara el mote de "persona más importante para la punición" a quien el poder político quisiera perseguir en particular. [...] De modo que la apertura a la discriminación y la arbitrariedad no podrían ser evitadas en la aplicación concreta de la disposición. (p. 9)

Por otro lado, partiendo de la premisa de que la celebración del acuerdo de colaboración implica directamente la libertad durante el proceso, Figueroa sostuvo:

... la aplicación de la norma impugnada [...] resulta violatoria de las previsiones que en ese orden jurídico consagran el principio de igualdad, pues la condición de igual trato debe originarse en función de idénticas circunstancias y condiciones, [...] si todos gozan uniforme e indistintamente de la presunción de inocencia, no resulta ajustado a derecho que quienes delatan son "beneficiados" con libertad durante el proceso y quienes no lo hacen, tienen como respuesta la prisión preventiva, como sucedió en el caso sujeto a nuestro control jurisdiccional. ${ }^{57}$

57 Cámara Federal de Casación Penal, Sala I: De Vido, Julio Miguel y otros s/recurso de casación, voto de 
Entonces, en función de las personas que pueden o no acceder al beneficio y su forma de selección, se argumenta que la ley discrimina ilegítimamente a: i) quienes tardan más en ofrecer su declaración como imputados colaboradores; y ii) a quienes están menos implicados en una organización delictiva frente a aquellos más implicados, dado que aquellos no poseerían información relevante para aportar a un acuerdo de colaboración, mientras que estos, siendo más culpables, sí podrían ser beneficiados por el instituto analizado. Además, también podría criticarse el hecho de que: iii) el instituto estaría dejando en manos del fiscal la discreción absoluta para seleccionar a los imputados que pueden o no efectuar un acuerdo de colaboración; y que iv) las exclusiones de los procesos de crímenes de lesa humanidad y de quienes sean o hayan sido funcionarios susceptibles de juicio político es arbitraria.

Sumadas a las anteriores discriminaciones, también se argumenta que la ley resulta violatoria del principio de igualdad en tanto distingue: v) a los imputados que eligen no declarar como colaboradores, ya que tendrían una pena mayor que aquellos que sí lo hicieran, de modo tal que, a pesar de tener igual culpa, tendrían distinta pena; ${ }^{58}$ y vi) a los imputados que eligen no acogerse al instituto del arrepentido, porque serían tratados desigualmente en relación al mantenimiento de la libertad durante el proceso.

\subsubsection{La igualdad ante la ley en la Constitución Nacional y la jurisprudencia de la Corte Suprema de Justicia de la Nación}

El principio de igualdad se encuentra definido primeramente en el artículo 16 de la Constitución Nacional, en tanto establece que "[1]a Nación Argentina no admite prerrogativas de sangre, ni de nacimiento: no hay en ella fueros personales ni títulos de nobleza. Todos sus habitantes son iguales ante la ley...”.

Pero al igual que con la garantía contra la autoincriminación forzada, las previsiones constitucionales relativas al principio de igualdad ante la ley no se agotan en el texto constitucional, sino que a partir de la reforma de 1994 también quedaron plasmadas en los instrumentos internacionales de derechos humanos con jerarquía constitucional.

En efecto, con una clara referencia a la igualdad formal, el artículo 2 de la Declaración Americana de los Derechos y Deberes del Hombre ordena que

Ana María Figueroa, apartado 2.3.d.

En este sentido también, Alén (2018). 
"Todas las personas son iguales ante la ley y tienen los derechos y deberes consagrados en esta declaración sin distinción de raza, sexo, idioma, credo ni otra alguna”. Otros instrumentos, como el artículo 7 de la Declaración Universal de Derechos Humanos, el artículo 26 del Pacto Internacional de Derechos $\mathrm{Ci}$ viles y Políticos, y el artículo 24 de la Convención Americana sobre Derechos Humanos, hacen referencia no solo a que todas las personas son iguales ante la ley, sino que tienen derecho, sin discriminación, a igual protección de la ley, además de proyectar este derecho a la igualdad al ejercicio de otros derechos. Luego se encuentran instrumentos que hacen referencia específicamente a la igualdad y prohibición de discriminación entre grupos de personas determinados, por motivos de raza, color, sexo, idioma, religión, opiniones políticas o de cualquier índole, origen nacional o social, posición económica, nacimiento o cualquier otra condición social..$^{59}$

Ahora bien, definida la normativa aplicable en general, resulta útil al efecto de analizar las críticas a la Ley 27304 precisar el alcance que se le ha otorgado a nuestra garantía de igualdad ante la ley.

En la doctrina de la Corte Suprema de Justicia de la Nación, desde 1875 inveteradamente ${ }^{60}$ se ha definido que

... la garantía de igualdad ante la ley radica en consagrar un trato legal igualitario a quienes se hallan en una razonable igualdad de circunstancias [...], lo que no impide que el legislador contemple de manera distinta situaciones que considere diferentes, en la medida en que dichas distinciones no se formulen con criterios arbitrarios, de indebido favor o disfavor, privilegio o inferioridad personal o clase, ni importen ilegítima persecución de personas o grupos de ellas. ${ }^{61}$

59 Además de los instrumentos referidos, puede citarse, por ejemplo, la Convención Internacional sobre la Eliminación de todas las formas de Discriminación Racial, la Convención sobre la Eliminación de todas las formas de Discriminación contra la Mujer, la Convención sobre los Derechos de las Personas con Discapacidad y su protocolo facultativo -estas con jerarquía constitucional- y la Convención Interamericana para Prevenir, Sancionar y Erradicar la Violencia contra la Mujer.

60 V.gr., Corte Suprema de Justicia de la Nación, Guillermo Olivar, por complicidad en el delito de rebelión; sobre fianza de juzgado y sentenciado y desacato, 01/05/1895, Fallos: 16:118, remitiendo a la sentencia del juez de sección De la Torre. Asimismo, del mismo tribunal, Geddes Hnos. y otros c/Provincia de Buenos Aires, 17/07/1902, Fallos: 95:327; Paz, doctor José Clemente, su testamentaria, 20/05/1915, Fallos: 117:22; Don Julio Sánchez Viamonte, en autos con el doctor Emilio Giustinian, sobre falsedad, 29/04/1916, Fallos: 123:106; Santoro, Cayetano c/Frias, Estela, 28/09/1916, Fallos: 124:122; Burrueco Mansilla, Rodolfo, en la causa que se le sigue ante los Tribunales Militares de la Nación, por hurto, 13/10/1917, Fallos: 126:280.

61 Corte Suprema de Justicia de la Nación, García, María Isabel c/AFIP s/acción meramente declarativa de inconstitucionalidad, 26/03/2019, Fallos: 342:411. 
Entonces, la igualdad a la que hace referencia la Constitución no se trata de un igualitarismo estanco que eliminaría las justas diferencias que emanan de la libertad, sino que manda a que todos los habitantes de la Nación sean tratados formalmente con igualdad ante la ley, que gocen de una igual protección de la ley, prohibiendo las discriminaciones arbitrarias. Como enseña Quiroga Lavié et al. (2009):

\begin{abstract}
Si la igualdad ante la ley implica diferenciar a los diferentes, entonces es constitucional que la ley realice clasificaciones o categorizaciones para atender en forma diferente a los miembros de cada clase, siempre que no se recurra a diferenciaciones arbitrarias, carentes de fundamento suficiente. Para ello, se necesita analizar dos elementos: el factor de discriminación elegido y la correlación con el tratamiento desigual (lo que se identifica con el principio de razonabilidad), puesto que no basta aducir cualquier razón para que un distinto tratamiento sea justificado. (pp. 403-404)
\end{abstract}

Ahora bien, esta facultad de realizar discriminaciones razonables en la legislación se encuentra naturalmente confiada al Congreso de la Nación, máxime en materia penal. Tal como ha expresado la Corte Suprema,

\begin{abstract}
... la garantía del art. 16 de la Constitución Nacional no impone una rígida igualdad, pues entrega a la discreción y sabiduría del Poder Legislativo una amplia latitud para ordenar y agrupar, distinguiendo y clasificando los objetos de la legislación, siempre que las distinciones o clasificaciones se basen en diferencias razonables y no en propósitos de hostilidad contra determinadas clases o personas. ${ }^{62}$
\end{abstract}

\title{
3.2.3. La finalidad de la Ley 27304 y la razonabilidad en la discriminación de la persona que puede obtener el beneficio y su forma de selección
}

Sentado ello, teniendo en cuenta que la Ley 27304 reconoce como antecedente el artículo 37 de la Convención de las Naciones Unidas contra la Corrupción, ${ }^{63}$ y analizando el texto mismo de la ley, queda claro que el fin del instituto es dotar a los operadores de la administración de justicia penal de una herramienta para lograr avanzar en la investigación de los delitos previstos por el artículo 1 de aquella ley. En función de este objetivo, se resigna de aplicar la condena ordinaria a un imputado a cambio de que brinde

62 Corte Suprema de Justicia de la Nación, García Monteavaro, Julio Efrain c/Amoroso y Pagano, 14/06/1957, Fallos: 238:60; y Fernández, Eduardo c/TA. La Estrella SA. s/despido, 10/06/1992, Fallos: 315:1190.

63 Vid. nota al pie 17. 
datos o información aportada [que] contribuyan a evitar o impedir el comienzo, la permanencia o consumación de un delito; esclarecer el hecho objeto de investigación u otros conexos; revelar la identidad o el paradero de autores, coautores, instigadores o partícipes de estos hechos investigados o de otros conexos; proporcionar datos suficientes que permitan un significativo avance de la investigación o el paradero de víctimas privadas de su libertad; averiguar el destino de los instrumentos, bienes, efectos, productos o ganancias del delito; o indicar las fuentes de financiamiento de organizaciones criminales involucradas en la comisión de los delitos previstos...

En igual sentido, el juez Gustavo Hornos ha sostenido que

... se trata de un mecanismo procesal que aporta a satisfacer el interés general de la sociedad para alcanzar la eficacia en la investigación del delito, en tanto contribuye a la más rápida y pronta administración de justicia a la par que resguarda la eficiencia de las garantías constitucionales, en un adecuado equilibrio dentro del conflicto de intereses que representa toda causa penal. ${ }^{64}$

Consecuentemente, dado que el fin del instituto es avanzar en la investigación de un hecho delictivo o impedir otros, que es un fin legítimo que no repugna a la Constitución, el criterio diferenciador principal del instituto para la selección de las personas que pueden ser imputados colaboradores será por el valor de la información que posean referida a sujetos de igual o mayor responsabilidad. La ley no impide que las personas con menor responsabilidad en el delito accedan al beneficio mediante la adhesión al instituto del imputado colaborador -ello sí lesionaría el principio de igualdad en tanto sería arbitraria-, sino que meramente se sujeta su procedencia al aporte de información útil en los términos antes descriptos, que es una categoría objetiva, adecuada y razonable para el fin buscado por la ley.

El mismo argumento le cabe a la crítica sobre la exclusión de quienes tardan en arrepentirse porque su información ya dejó de ser útil. A estos imputados no se los discrimina por demorarse en elegir declarar, sino que la diferenciación dependerá exclusivamente del valor de dicha información al momento de ofrecerse el aporte. Lo contrario sería manifiestamente contraproducente, ya que el imputado que se negó a declarar al principio sobre una información que luego fue conocida por el fiscal o juez por vía de otros elementos probatorios o por

64 Cámara Federal de Casación Penal, Sala IV: Legajo de arrepentido. Ferreyra, Claudio Marcelino por asociación ilícita art. 303 inc. 1, 5/6/2019, [FCB 058814/2017/31/CFC001, Registro 1140/19.4]. 
la declaración de otro imputado podría luego pretender acceder a un beneficio por contarle al fiscal y juez lo que ya saben, sin que se genere avance alguno en la investigación.

Igualmente, incluso de considerarse el caso de un imputado de menor responsabilidad que no pueda acceder al beneficio de la Ley 27304 por no tener información útil para aportar, mientras que sí la tendría un imputado de responsabilidad intermedia en la organización, difícilmente pueda pensarse que estamos ante una distinción arbitraria. Ello, dado que quien comete un delito no posee el derecho a ser beneficiado por no poseer información, sino que le corresponderá la pena según las normas penales ordinarias. El beneficio es una excepción a las normas comunes, no la regla. Justamente, la nota característica para la procedencia de este beneficio es que se aporte información, y ello no constituye una distinción arbitraria de modo tal que configure una prerrogativa de sangre o que se vulnere la igualdad formal ante la ley.

Como sostuvo Diego Barroetaveña en el citado fallo De Vido,

... la denunciada desigualdad de trato que establecería la mencionada ley entre quienes estarían más involucrados en la organización y los que ocuparían roles menores en nada cambia el hecho de que cualesquiera de ellos podría aportar información en contra de los intereses de su defendido. A lo expuesto es dable agregar que el criterio esencial de distinción es el "aporte de información" y no el lugar que cada imputado ocupa dentro de la organización supuestamente criminal, con lo cual el reproche ético que el defensor formula en cuanto al mensaje que estaría comunicando la norma al permitir mayores beneficios a quienes estarían más implicados [...] resulta ajeno a la incumbencia del Poder Judicial. ${ }^{65}$

En este sentido, corresponde resaltar que dado que resulta muy dificultoso determinar ex ante y en general qué información es relevante o irrelevante, o quién tiene mayor o menor responsabilidad en un hecho delictivo al efecto de la Ley 27304, esta aplicación de la norma queda a cargo primeramente del representante del Ministerio Público Fiscal que decide realizar o no el acuerdo. Empero, esta decisión, por la naturaleza misma de este poder del Estado, no puede ser arbitraria o discriminatoria.

Es que el Ministerio Público tiene la misión general de "promover la actuación de la justicia en defensa de la legalidad de los intereses generales de la sociedad", como establece el artículo 120 de la Constitución Nacional, y la de

65 Cámara Federal de Casación Penal, Sala I: De Vido, Julio Miguel y otros s/recurso de casación, voto de Diego Gustavo Barroetaveña, apartado III.b.1. 
"velar por la efectiva vigencia de la Constitución Nacional y los instrumentos internacionales de derechos humanos en los que la República sea parte y procurar el acceso a la justicia de todos los habitantes", como manda el artículo 1 de la Ley Orgánica del Ministerio Público Fiscal de la Nación. ${ }^{66}$ Además, tiene el deber concreto de formular "motivada y específicamente, sus requerimientos y conclusiones" ${ }^{67}$ o de "motivar sus requerimientos y resoluciones", ${ }^{68}$ y posee como principio de actuación funcional el de la objetividad, por el cual "requerirá la aplicación justa de la ley, procurando el resguardo equilibrado de todos los valores y principios jurídicos vigentes y el ejercicio racional y ponderado del poder penal del Estado". ${ }^{69}$

Por consiguiente, la norma no solo prevé que el fiscal debe guiar su criterio de selección de los imputados que deseen acogerse al instituto del imputado colaborador de una manera objetiva, ecuánime y fundada, sino que incluso un rechazo arbitrario o discriminatorio podría ser eventualmente discutido por vía de un procedimiento dentro del propio Ministerio Público Fiscal o solicitándole al juez que declare la nulidad de dicho rechazo.

Por otro lado, a pesar de que en casos de delitos de lesa humanidad la conmutación parcial de penas en nada contradice la jurisprudencia internacional ${ }^{70}$ y que solo se encuentra constitucionalmente prohibida en casos de actos de fuerza contra el orden institucional y el sistema democrático y para quienes en tal contexto usurpen las funciones previstas para las autoridades constitucionales federal y estaduales ${ }^{71}$ tampoco es arbitraria la exclusión de los beneficios de la Ley 27304 de los procesos de crímenes de lesa humanidad. Resulta legítimo que el Estado pretenda no ceder en el castigo de estos delitos aberrantes que atentan contra la dignidad misma del hombre, lo que es concordante con

66 Ley 27148 de Ley Orgánica del Ministerio Público Fiscal, BO 18/06/2015.

67 Código Procesal Penal de la Nación, artículo 69.

68 Código Procesal Penal Federal, artículo 90.

69 Ley 27148 de Ley Orgánica del Ministerio Público Fiscal, BO 18/06/2015, artículo 9, inc. d).

70 La Corte Interamericana de Derechos Humanos desde el caso Barrios Altos vs. Perú (14/03/2001) sostiene que son "inadmisibles las disposiciones de amnistía, las disposiciones de prescripción y el establecimiento de excluyentes de responsabilidad que pretendan impedir la investigación y sanción de los responsables de las violaciones graves de los derechos humanos". Esta doctrina fue citada por el voto de mayoría de la Corte Suprema de Justicia de la Nación a partir del año 2004 desde el precedente Arancibia Clavel (Corte Suprema de Justicia de la Nación, Arancibia Clavel Enrique Lautaro s/homicidio calificado y asociación ilícita y otros -Causa n² 259, 24/08/2004, Fallos: 327:3312). Lo prohibido, según esta interpretación jurisprudencial, sería la impunidad, mas no una conmutación parcial de la pena.

71 Artículo 36 de la Constitución Nacional: "Esta Constitución mantendrá su imperio aun cuando se 
la prohibición de conmutación de penas previsto por el artículo 1 de la Ley $27156 .{ }^{72}$ Esto, más allá de que pueda resultar discutible el acierto o desacierto de exclusión de este instituto de las personas que tuvieron una pequeña responsabilidad en delitos de lesa humanidad, por cuanto se podría lograr romper con los pactos de silencio y penar a quienes tuvieron una mayor responsabilidad, evitando su impunidad.

De manera semejante, tampoco resulta irrazonable la exclusión de la Ley 27304 respecto a quienes sean o hayan sido funcionarios públicos susceptibles de juicio político, es decir, el presidente, vicepresidente, jefe de gabinete de ministros, ministros secretarios y miembros de la Corte Suprema de Justicia de la Nación. ${ }^{73}$ Los delitos cometidos por estas personas, en razón del deber especial para con la sociedad, las leyes y la Constitución, debilitan gravemente a la sociedad y su confianza en las leyes e instituciones republicanas ${ }^{74}$ y son especialmente aberrantes y escandalosos, resultando intolerable cualquier tipo de lenidad para con ellos.

Es más, no puede dejarse de lado que por imperio del artículo 36 de la Constitución Nacional nuestro derecho considera que atenta "contra el sistema democrático quien incurriere en grave delito doloso contra el Estado que conlleve enriquecimiento". Ciertamente, la impunidad de los delitos cometidos por los altos funcionarios públicos socava las bases mismas del sistema democrático y rompe el vínculo que los une con el ciudadano que le confía por medio de su participación en el sufragio la administración de los intereses de la nación. Por demás, tampoco puede dejarse de lado el compromiso internacional asumido respecto a la lucha contra la corrupción en la citada Convención de las Naciones Unidas contra la Corrupción.

En definitiva, si bien no todos los delitos previstos en el artículo 1 de la Ley 27304 son delitos de corrupción, las distintas características de los funcionarios antes nombrados hacen que sea razonable su exclusión, puesto que en función

interrumpiere su observancia por actos de fuerza contra el orden institucional y el sistema democrático. Estos actos serán insanablemente nulos. Sus autores serán pasibles de la sanción prevista en el Artículo 29, inhabilitados a perpetuidad para ocupar cargos públicos y excluidos de los beneficios del indulto y la conmutación de penas. Tendrán las mismas sanciones quienes, como consecuencia de estos actos, usurparen funciones previstas para las autoridades de esta Constitución o las de las provincias, los que responderán civil y penalmente de sus actos. Las acciones respectivas serán imprescriptibles...”.

72 BO 31/07/2015.

73 Conf. Constitución de la Nación Argentina, artículo 53.

74 Sobre los preocupantes indicadores de desconfianza en las instituciones de la República y en el funcionamiento de la democracia, véase Observatorio de la Deuda Social Argentina (2018). 
de su vínculo estrecho con el orden jurídico no se encuentran en igualdad de condiciones que un ciudadano ordinario que delinque.

\subsubsection{La razonabilidad del beneficio de la Ley 27304 frente al principio de culpabilidad}

En otro orden de ideas, con relación al quiebre del principio de igualdad derivado de la imposición de penas disímiles ante un similar nivel de culpabilidad, tal argumento tampoco tiene una potencia suficiente para derivar en la inconstitucionalidad de la ley.

En este sentido, cabe recordar que, tal como lo resalta la doctrina realista del derecho penal, la pena es la consecuencia de la comisión de un delito, que causa el demérito derivado de la violación de dos deberes: a) de respetar la relación del titular del bien jurídico con este, que surge de la justicia conmutativa; y b) de respetar la paz y la vida tranquila de la comunidad, derivado de la justicia general dirigida directamente a preservar el bien común (Repetto, 2007). Es decir que el delito no afecta solamente el interés de un privado, sino también "a la república, violando la seguridad de su tutela" (Tomás de Aquino, II-II, q. XLI, artículo 4), la seguridad del orden del derecho de la comunidad en tanto cohíbe esas conductas consideradas negativas. Entonces, la medida del reproche penal -la culpabilidad- tiene lugar en razón del demérito objetivo (la afectación al tercero y a la comunidad) y subjetivo (la mayor o menor malicia al cometer el delito ${ }^{75}$ propio de su voluntad al momento de delinquir. Consecuentemente, a fin de restablecer la igualdad perturbada por el delito -es decir, hacer justicia- ${ }^{76}$ a ese demérito debe retribuírselo con una pena que le debe guardar proporción conmutativa o aritmética. En otros términos, la culpabilidad es la medida de "lo suyo" penal, la pena que en justicia le corresponde al delincuente por haber delinquido.

Pero sin perjuicio de ello, en nuestro ordenamiento penal existen casos en los que, ante una igual culpabilidad, se establecen excusas absolutorias relativas a la falta de necesidad de pena o fundadas en la protección de otros intereses. Ante la existencia de otros intereses sociales, muchas veces se resigna la aplicación ordinaria de la pena que en justicia le corresponde al imputado para lograr otro fin que conduce al bien común de la sociedad.

75 En este sentido, los artículos 40 y 41 del Código Penal ordenan valorar distintas circunstancias objetivas y subjetivas como atenuantes y agravantes al efecto de determinar las penas divisibles.

76 El fin retributivo de la pena es el fin esencial de esta, sin la cual dejaría de tener un real nexo con la culpabilidad del delincuente, mas no es el único fin de la pena en sus fases de conminación, aplica- 
Por ejemplo, el artículo 277, inciso 4 del Código Penal exime de responsabilidad penal a ciertos encubrimientos entre parientes, mientras que el artículo 185 exime de pena a una serie de familiares de las víctimas de hurtos, defraudaciones o daños, indicando expresamente que dicha excepción no es aplicable a los extraños que participen del delito. En estos casos, ante igual o similar culpabilidad, el legislador renuncia a la imposición de una pena respecto a uno y castiga al otro, incluso cuando el impune sea el autor; y el condenado, el partícipe. No obstante, en estos casos no se viola el principio de igualdad ante la ley, toda vez que esta distinción se vuelve razonable por el fin que buscan estas normas, que es la protección de la familia y su preeminencia ante otros intereses patrimoniales (D’Alessio, 2004, p. 575; Donna, 2007, pp. 860-861).

Algo similar sucede con el beneficio de la Ley 27304. Si bien puede haber una similar culpabilidad, el disímil tratamiento se justifica en el comportamiento del imputado posterior a la consumación del hecho, que tiene por objeto la colaboración con el Estado en la investigación. Este acto posterior en nada cambia su culpa pasada, pero sí logra al menos reducir la necesidad de la pena por coadyuvar a reparar aquello que antes quebrantó, el bien de la comunidad traducido en la vigencia de la tutela del Estado, la vigencia del derecho.

Así como ante el delito de injuria o calumnia la retractación posterior, sin eliminar la culpabilidad pasada, hace a la reparación -al menos parcial- del daño causado a la persona injuriada o calumniada (en tanto titular del bien jurídico), lo que ha llevado al legislador a eximir de pena al delincuente, ${ }^{77}$ también el imputado colaborador intenta reparar uno de los dos fundamentos de su lesión: la agresión a la paz y al orden de la comunidad mediante la infracción al derecho. Es decir, en función de los datos brindados por el imputado

ción y ejecución. En efecto, de manera mediata la pena puede por ejemplo tender hacia: la disuasión del delincuente, su neutralización o inocuización durante el encierro (prevención especial negativa), la disuasión al delito de otros miembros de la sociedad (prevención general negativa), resocialización y expiación de la culpa (prevención especial positiva) y fin pedagógico social (prevención general positiva).

Por su popularidad en la doctrina, es pertinente destacar que esta concepción difiere de los autores contemporáneos seguidores de Günther Jakobs, que adoptan la teoría de la "prevención general positiva" de la pena como su único fin, y hacen referencia a la función del derecho penal como solamente de aseguramiento de expectativas, de modo que no protege el contenido sino el deber formal mismo, la vigencia de las normas. Debe aclararse que, para esta concepción, el delito no lesiona a terceros, a la comunidad ni al valor justicia, sino que ataca las condiciones de vigencia de las normas, siendo esa perturbación social compensada con la pena, que contrafácticamente reafirma la vigencia de la norma atacada por el delito, reasegurando las expectativas de la generalidad de la sociedad derivadas de la norma atacada. Véase el estudio de un discípulo de Jakobs: Heiko Hartmut Lesch (2016).

Código Penal, artículo 117. 
colaborador, a pesar de renunciarse a una parte de la pena que le corresponde, se puede llegar a un resultado global más justo, por cuanto se logra retribuir penalmente también a delincuentes cuyos actos han lesionado de igual o mayor manera la paz y el orden que da el cumplimiento del derecho de la comunidad.

De ello se sigue el fundamento por el cual el legislador, en ejercicio del diseño prudencial de su política criminal -cuya oportunidad, mérito y conveniencia es ajena al control de los jueces-, ha optado por renunciar a aplicarle la totalidad de la pena al imputado arrepentido, beneficiándolo con una reducción de la escala penal, mas no la impunidad. Este consiste en que, en tanto la colaboración ayuda a castigar a otros delincuentes de igual o mayor responsabilidad, la delación premiada conlleva en sus efectos un restablecimiento -al menos parcial- de ese orden jurídico vulnerado por el delincuente delator, que es mayor al que habría si solo se le aplicara la pena al delator y, por lo tanto, logra una mayor justicia. Entonces, independientemente de los posibles motivos egoístas, toda vez que el imputado colaborador mediante su conducta posterior al hecho tiende a colaborar con el derecho -y, de esta forma, con la comunidad-, se reduce la necesidad de la pena. Por lo tanto, este beneficio de reducción de la escala penal resulta razonable, se encuentra dentro del margen de discreción del Poder Legislativo, lo que provoca que la distinción hecha por el legislador sea adecuada al principio de igualdad ante la ley, en suma, constitucional.

\subsubsection{Consideraciones finales respecto al principio de igualdad ante la ley}

Por último, con relación a la crítica dirigida a la diferenciación arbitraria respecto a la libertad durante el proceso, brevemente corresponde poner de resalto que, tal como se explicó anteriormente, dicha interpretación de la ley resulta errónea, de lo que se sigue que el agravio carece de sustento. Dado que la ley no beneficia a quien declara como imputado colaborador con la libertad durante el proceso y, principalmente, tampoco penaliza a quien elige no declarar, no hay violación alguna al principio de igualdad y al igual reconocimiento de la presunción de inocencia.

En resumen, la Ley 27304 efectúa distinciones para determinar quiénes pueden declarar como imputados colaboradores y acceder al beneficio de reducción de la escala penal, siendo estas diferenciaciones razonables para el fin de la norma, esto es, avanzar en la investigación de un hecho delictivo o impedir otros. En conclusión, estas diferenciaciones son perfectamente compatibles con el principio de igualdad ante la ley. 


\subsection{La irretroactividad de la ley penal más gravosa \\ 3.3.1. Críticas a la constitucionalidad del instituto}

Una tercera crítica contra la aplicación del instituto del imputado colaborador no tiene que ver con su vigencia en sí, sino con su utilización en la investigación de hechos cometidos con anterioridad a su sanción, respecto a cuyas calificaciones jurídicas era inaplicable el instituto. Según esta postura, ello entraría en contradicción con la garantía de la interdicción de la aplicación retroactiva de la ley penal más gravosa. En este sentido, estas críticas parten de la premisa de que las normas vigentes a partir de la sanción de la Ley 27304 son más gravosas que las existentes al momento de comisión de hechos anteriores a su entrada en vigencia.

La jueza Figueroa ha argumentado que la Ley 27304 resulta más gravosa para el conjunto de los imputados, por cuanto no sería posible considerar solamente a los colaboradores, sino que también debe considerarse a los afectados por sus declaraciones. Ello se debe a que, a su criterio,

... el estudio de los parámetros que den cuenta de su mayor benignidad debe recaer, integralmente, en la totalidad de las consecuencias de la manda legal y en el conjunto de los sujetos de derecho involucrados a partir de su aplicación, no puede aplicarse retroactivamente una ley que resulta más benigna para los arrepentidos y más gravosa para los imputados que no delaten. ${ }^{78}$

En este orden de ideas, entiende la citada jurista que

... desde un análisis centrado en las consecuencias generadas al imputado arrepentido, sin perjuicio del beneficio de reducción de la responsabilidad o de mejora de su situación procesal, cierto es que la ley 27.304 criminaliza una nueva conducta como delito, extremo que, desde este aspecto, descarta la benignidad del precepto legal a estudio [...]. Asimismo, respecto del imputado perjudicado por las manifestaciones del arrepentido, sin lugar a dudas estamos en presencia de una ley penal posterior más gravosa, pues su aplicación implica una imputación dirigida en su contra. Para quien resultare imputado producto de la delación del "arrepentido", se advierten dos agravios: uno de ellos referidos a que la figura que lo perjudica se ha aplicado respecto de delitos no contemplados por las normas vigentes al momento de los hechos y en segundo lugar, porque si bien para el sujeto delator su aplicación podría considerarse aisladamente beneficiosa [...], para el delatado por la declaración de ese coimputado, el perjuicio es osten-

78 Cámara Federal de Casación Penal, Sala I: De Vido, Julio Miguel y otros s/recurso de casación, voto de Ana María Figueroa, apartado 3.3. 
sible en la medida que pasa a estar denunciado en los términos de una declaración de quien tiene derecho a mentir para mejorar su situación procesal, y como resultado pasa a tener sobre sus espaldas el peso de una investigación penal que lo tiene como presunto autor, coautor o partícipe de un delito concreto. ${ }^{79}$

En consecuencia, las críticas alrededor de esta garantía en casos en los que los hechos juzgados son anteriores a la sanción de la Ley 27304 se centran en: i) que la ley no es más benigna para el imputado colaborador porque se establece el delito de suministro malicioso de datos falsos o inexactos del imputado colaborador; ii) que el delito del artículo 276 bis viola la garantía cuando el objeto de la declaración se refiere a hechos anteriores a la fecha de su sanción; y iii) que un análisis de la aplicación integral de la norma conduce a que se aplique un método de investigación más gravoso para los señalados por los imputados colaboradores, el cual no estaba previsto al momento de comisión de los hechos delictivos que sufre una investigación penal.

\subsubsection{La irretroactividad de la ley penal más gravosa en el derecho argentino}

Tradicionalmente se les ha asignado a los principios de legalidad y de reserva, previstos en los artículos 18 y 19 de la Constitución Nacional, la exigencia de cuatro requisitos para que sea procedente la aplicación de una ley -en sentido formal y material- penal: que sea previa (lex praevia), escrita (lex scipta), cierta (lex certa) y estricta (lex stricta, prohibición de la analogía) (Righi, 2015, pp. 69-73). La cuestión de la irretroactividad hace referencia al primero de estos caracteres, a la necesidad de una ley anterior al hecho del proceso.

Por otro lado, una referencia clara a esta garantía surge de los tratados internacionales de derechos humanos con jerarquía constitucional, que ayudan a determinar los alcances de esta garantía.

Efectivamente, la Convención Americana sobre Derechos Humanos establece en su artículo 9:

Nadie puede ser condenado por acciones u omisiones que en el momento de cometerse no fueran delictivos según el derecho aplicable. Tampoco se puede imponer pena más grave que la aplicable en el momento de la comisión del delito. Si con posterioridad a la comisión del delito la ley dispone la imposición de una pena más leve, el delincuente se beneficiará de ello.

79 Ídem. 
Por su parte, la Declaración Universal de Derechos Humanos prescribe en su artículo 11.2 que: "Nadie será condenado por actos u omisiones que en el momento de cometerse no fueron delictivos según el Derecho nacional o internacional. Tampoco se impondrá pena más grave que la aplicable en el momento de la comisión del delito”. Por último, el artículo 15.1 del Pacto Internacional de Derechos Civiles y Políticos señala:

\begin{abstract}
... Nadie será condenado por actos u omisiones que en el momento de cometerse no fueran delictivos según el derecho nacional o internacional. Tampoco se impondrá pena más grave que la aplicable en el momento de la comisión del delito. Si con posterioridad a la comisión del delito la ley dispone la imposición de una pena más leve, el delincuente se beneficiará de ello...
\end{abstract}

Es decir, de la letra de la Constitución y los tratados mencionados se desprende inequívocamente que la garantía de no aplicación retroactiva de la ley penal más gravosa se refiere a dos aspectos bien definidos: al hecho tipificado como delictivo y a la pena. Lo que prohíbe entonces dicha garantía es penar conductas que, al momento de su comisión, no eran consideradas delictivas y crear o agravar penas más allá de las vigentes al momento de comisión del hecho (Badeni, 2006, p. 1079).

Ese y no otro es el alcance correcto de la garantía, y así lo interpretó la Corte Suprema de Justicia de la Nación en el fallo Gerstein, en el que resolvió un caso de aplicación retroactiva de una multa más grave que la prevista al momento de comisión del hecho, siendo su doctrina que

... el principio de legalidad consagrado por el art. 18 de la Constitución Nacional nace de la necesidad de que haya una ley que mande o prohíba una conducta, para que una persona pueda incurrir en falta por haber obrado u omitido obrar en determinado sentido, y que además se determinen las penas a aplicar [...]. Consecuentemente, de dicha norma constitucional, que consagra el principio de nulli crimen, nulla poena sine lege, se desprende que la ley penal no puede ser retroactiva ni en cuanto a la descripción del tipo legal ni en cuanto a la adjudicación de la sanción. Las leyes ex post facto prohibidas por la Constitucional Nacional -ha sostenido esta Corte- son las que se refieren a la definición de los delitos y las penas... ${ }^{80}$

Por otro lado, y en directa relación con el tema bajo estudio, resulta aplica-

80 Corte Suprema de Justicia de la Nación, Gerstein, Myriam Noemí s/infracción ley 20.771, art. 2, inc. a), 
ble lo sostenido por el procurador general de la nación Juan Álvarez en el caso Spotorno, a cuyos fundamentos se remitió la Corte Suprema, ${ }^{81}$ en tanto opinó:

El hecho de que para la comprobación de una infracción se haya aplicado un procedimiento judicial que el infractor entiende no es el que regía en el momento de cometerse el hecho reprimido, no puede vulnerar garantía constitucional alguna, si, como en el caso de autos, no se alega que el procedimiento aplicado sea inconstitucional, en sí, por vulnerar la libertad de defensa en juicio y otra garantía de carácter federal. No puede hablarse de derecho adquirido a ser juzgado por un determinado procedimiento, dado que las leyes de este tipo son de orden público. Las leyes ex post facto inaplicables en el concepto constitucional, son las que se refieren a delitos y no las que estatuyen acerca de la manera de descubrirlos y perseguirlos.

Dicha doctrina fue posteriormente reiterada por la Corte misma frente a la creación del fuero Nacional en lo Penal Económico, sosteniendo que "no existe derecho adquirido a ser juzgado por un determinado procedimiento, ya que tales leyes son de orden público, especialmente cuando se estatuyen acerca de la manera de descubrir y perseguir los delitos". ${ }^{82}$

Por último, ha de señalarse que al efecto de evaluar si una ley penal es más gravosa o más benigna, es doctrina de la Corte -incluso sin una previsión expresa como el artículo 900 del Código Aduanero- ${ }^{83}$ que cuando la ley penal sancionada con posterioridad al hecho incriminado depare un tratamiento más favorable al imputado, ella debe ser aplicada íntegramente, incluyendo aquellos aspectos que individualmente considerados resulten desventajosos con relación a la ley anterior. Este imperativo les impide a los jueces construir una norma con los aspectos más benévolos de leyes sucesivas, quienes, de lo contrario, aparecerían finalmente sustituyendo al legislador en la valoración de la conducta creando una tercera ley, en clara oposición al principio según el cual le compete al Poder Legislativo establecer las disposiciones que contemplen los hechos punibles y las respectivas sanciones tras su propia apreciación de las conductas reprobables. ${ }^{84}$

c) y d), 20/12/1988, Fallos: 311:2721. Con cita de Fallos: 304:892 y 181:288.

81 Corte Suprema de Justicia de la Nación, Spotorno, Ángel, 22/08/1938, Fallos: 81:288.

82 Corte Suprema de Justicia de la Nación, Cafés, Chocolates Águila y Productos Saint Hnos. S.A., 20/03/1961, Fallos: 249:343.

83 Código Aduanero, artículo 900: "Para establecer cuál es la norma penal más benigna se debe comparar la totalidad del contenido de las normas penales de las leyes cuya aplicación correspondiere".

84 Cfr. Dictamen del procurador fiscal ante la Corte Suprema de Justicia de la Nación, Eduardo 


\subsubsection{La aplicación en el tiempo de la Ley 27304}

De las maneras que han sido señaladas por sus críticos, la Ley 27304 no es verdaderamente una ley penal que se esté aplicando retroactivamente.

Primeramente, al efecto de este análisis debe examinarse, por un lado, la posibilidad del imputado de declarar como colaborador y su beneficio -y los efectos que proyectan tanto en el imputado colaborador como en la persona señalada por este-, y, por otro lado, el delito del artículo 276 bis del Código Penal.

Así entonces, respecto a quien decide ser imputado colaborador, el régimen procesal de la declaración y el beneficio penal no es una ley penal más gravosa en el sentido de la garantía bajo estudio, en tanto no crea ni agrava una pena, ni considera delictivo un hecho que no lo era al momento de su comisión. Al contrario, esta ley meramente establece un mecanismo procesal novedoso -antes no vigente para algunos delitos- con el fin de obtener información de imputados que quieran ser colaboradores a cambio de un beneficio penal, carácter que no se ve alterado por el hecho de que este mecanismo procesal esté reforzado por la existencia de un nuevo delito. El hecho de que con anterioridad a la sanción de esta ley el imputado haya estado autorizado a colaborar con el juez en la declaración indagatoria sin consecuencias en caso de mentir en nada afecta la constitucionalidad del instituto, siendo que además dicha posibilidad sigue estando vigente, aunque naturalmente no le corresponda el beneficio de reducción de la escala penal.

Idéntica tesitura corresponde adoptar respecto a las personas señaladas por el imputado como partícipes de un hecho delictivo en el acuerdo de colaboración. Es que la creación de un instituto procesal con potencialidad probatoria -ya que en sí misma la declaración del imputado colaborador no resulta un elemento probatorio suficiente, sino un indicio a ser corroborado por otras evidencias-, no afecta en ningún sentido la prohibición de la retroactividad de la ley penal más gravosa, sencillamente porque no es una ley penal en el sentido antes señalado, sino -se reitera- una norma procesal. A este respecto, resulta plenamente aplicable la jurisprudencia de la Corte antes reseñada, según la cual no existe derecho adquirido a ser juzgado por un determinado procedimiento, especialmente cuando se estatuyen acerca de la manera de descubrir y perseguir los delitos. Entonces, el análisis integral para la comparación de las leyes penales que se suceden en el tiempo, tal como emana de la doctrina de la

Ezequiel Casal, al que se remitió la Corte Suprema de Justicia de la Nación en Revello Carlos Agustín y otros s/abuso de autoridad en los términos del art. 248 del Código Penal-Causa $N^{\circ}$ 10503, 21/11/2006, Fallos: 329:5323, R. 1972. XLI. RHE. 
Corte Suprema de Justicia de la Nación, hace referencia solamente a los hechos punibles y las sanciones, mas no a cualquier tipo de efecto de la nueva ley.

En consecuencia, carece de sustento la idea de que un coimputado tiene derecho en base a esta garantía a que el imputado arrepentido no se refiera a hechos anteriores a la sanción de la Ley 27304, porque este coimputado no se ve afectado por el nuevo tipo penal, dado que no se le aplica un delito novedoso o más gravoso a una conducta propia previa. En todo caso, la circunstancia de la oportunidad procesal para que el imputado colaborador declare no tiene naturaleza penal, sino meramente instrumental, de lo que se deriva que nadie tiene derecho a que otro no brinde pruebas en su contra, con las excepciones de las prohibiciones de declarar de la ley procesal.

Es más, aun antes de la sanción de esta ley, el coimputado estuvo siempre habilitado legalmente a hacer un descargo y ofrecer pruebas que lo desincriminen o que incriminen a un tercero, y ello era susceptible de evaluación al momento de graduar la eventual pena. El hecho de que el imputado colaborador tenga un beneficio penal en todo caso servirá para evaluar la credibilidad de sus declaraciones, respecto a las cuales la ley enfáticamente ordena que no sean tomadas en cuenta como prueba suficiente de los hechos, tal como establece el estándar de la Corte Interamericana de Derechos Humanos. ${ }^{85}$

Un planteo como el de la crítica relativo a que este instituto perjudica materialmente a las personas señaladas por el colaborador importaría sostener análogamente, por ejemplo, que no se podría utilizar la prueba de ADN obtenida de manera forzosa, incorporada al Código Procesal Penal de la Nación por la Ley 26549 en el año 2009 y reforzada por el delito de desobediencia o resistencia contra una autoridad en cumplimiento de una orden a tal efecto. Según esta postura, la aplicación de este medio probatorio a un hecho delictivo cometido con anterioridad a su sanción sería violatoria de la garantía analizada, porque sería un instituto procesal probatorio novedoso respaldado por un tipo penal. Este ejemplo análogo da cuenta de lo lábil que resulta este argumento crítico de la Ley 27304.

Por otro lado, tampoco puede ser de recepción el argumento relativo a la presunta violación de la garantía contra la irretroactividad de la ley penal más

85 Cfr. Corte Interamericana de Derechos Humanos, Zegarra Marin us. Perú, Excepciones Preliminares, Fondo, Reparaciones y Costas, 15/02/2017, párrs. 127 y siguientes; y Corte Interamericana de Derechos Humanos, Ruano Torres y otros vs. El Salvado, Fondo, Reparaciones y Costas, 05/10/2015, párr. 133. Esta forma de valoración de la declaración del arrepentido salva a las críticas formuladas por quienes consideran que se lograran condenas erróneas (v.gr., Hendler, 1998). 
gravosa por la aplicación del artículo 276 bis del Código Penal ${ }^{86}$ cuando el objeto de la declaración del imputado colaborador se refiere a hechos anteriores a la fecha de su sanción, porque se asienta en una premisa errónea. El objeto del delito es la acción de brindar maliciosamente declaraciones falsas o inexactas al declarar como imputado colaborador, no el contenido de aquella declaración, que sería en todo caso el objeto mediato del delito.

Coincidiendo con Barroetaveña, en este tipo penal

... el momento de comisión del hecho sobre el que se ancla el principio de legalidad es el de prestar declaración. Y ello es así porque como en el caso del art. 275 del mismo código -en todo cuanto pueda ser tomado como parámetro-, se trata de un delito que se consuma de manera instantánea al momento de producirse la deposición, cuestión sobre la que prácticamente existe unanimidad en la doctrina. ${ }^{87}$

Por ende, no se está penando una conducta previa no delictiva al momento del desarrollo ni agravando la pena a ella aplicable. Al contrario, este tipo penal prevé una sanción para conductas posteriores a su incorporación al ordenamiento jurídico, que son las declaraciones de los imputados colaboradores.

Entonces, no se da el caso de la necesidad de comparación de normas en las que haya que evaluar si las leyes vigentes anteriores a la sanción de la Ley 27304 eran o no más benignas. Ello, simplemente porque en nada afecta esta ley a los hechos pasados, ya que era imposible la comisión de este delito por cuanto no existía uno de sus elementos típicos: la declaración en los términos del artículo 41 ter del Código Penal.

En función de lo antedicho, cabe concluir que la Ley 27304 no es verdaderamente una ley penal más gravosa susceptible de ser aplicada retroactivamente, motivo por el cual carecen de sustento las críticas referidas a la violación de la garantía tratada.

\section{Conclusiones}

La regulación de la delación premiada, más allá de las objeciones constitucio-

86 Código Penal, artículo 276 bis: "Será reprimido con prisión de cuatro (4) a diez (10) años y con la pérdida del beneficio concedido el que, acogiéndose al beneficio del artículo 41 ter, proporcionare maliciosamente información falsa o datos inexactos".

87 Cámara Federal de Casación Penal, Sala I: De Vido, Julio Miguel y otros s/recurso de casación, voto de Diego Gustavo Barroetaveña, apartado III.b.3. 
nales argüidas por los doctrinarios y jueces, se adecua perfectamente dentro del margen de discreción política del legislador. Este instituto no viola ningún principio, derecho o garantía constitucional, vistos los verdaderos alcances que tienen la garantía contra la autoincriminación forzada, el principio de igualdad ante la ley y la garantía contra la aplicación retroactiva de la ley penal más gravosa.

Una recta comprensión del libre albedrío como principio de la voluntad deriva en que ni el beneficio que la ley otorga al imputado colaborador, ni la probabilidad del otorgamiento de la libertad durante el proceso ni la pena en caso de suministrar información falsa en el marco de la delación son en sí mismos condicionamientos ilegítimos que atenten contra la libertad del imputado colaborador. Estos caracteres de la ley no implican verdaderamente una obligación o compulsión a la autoincriminación por eliminar la voluntariedad de la declaración, máxime cuando la decisión del imputado de rechazar el acuerdo no conlleva ninguna penalidad o presunción en su contra. Tal decisión, que es tomada junto al defensor y cuya voluntariedad es posteriormente controlada por el juez en una audiencia prevista a tal efecto, está normativamente prevista para ejercerse en plena libertad real, sin violencia o coacción, con el solo efecto para el imputado de deber hacerse responsable de las legítimas consecuencias que emanen de su elección.

Por otro lado, toda vez que el fin del instituto del imputado colaborador es avanzar en la investigación de un hecho delictivo o impedir otros, que es un fin legítimo que no repugna a la Constitución Nacional, el criterio diferenciador principal del instituto para la selección de aquellos que pueden ser delatores premiados está dado por el valor de la información que posean referida a sujetos de igual o mayor responsabilidad criminal. Esta discriminación que realiza la Ley 27304 al efecto de seleccionar a las personas que pueden acogerse al instituto y la forma de selección -que el fiscal debe realizar de manera objetiva, ecuánime y fundada-, al igual que la exclusión de los delitos de lesa humanidad y los imputados que ejerzan o hayan ejercido altos cargos de la nación, resulta jurídicamente razonable conforme a la jurisprudencia relativa al principio de igualdad ante la ley.

De igual modo, en función de la naturaleza de la conducta posdelictual del arrepentido, no es violatorio del principio de igualdad ante la ley el beneficio de reducción de la escala penal en comparación con los coimputados que tengan una similar culpabilidad que no se acogen al instituto. Ello, por cuanto -a diferencia de los otros coimputados- el imputado colaborador coadyuva a castigar a otros delincuentes de igual o mayor responsabilidad y, de esta forma, 
a restaurar la paz de la comunidad perturbada por su delito, lográndose una mayor justicia, lo que torna razonable el beneficio.

Por último, dados los reales alcances de la garantía contra la aplicación retroactiva de la ley penal más gravosa, en tanto prohíbe penar conductas que al momento de su comisión no eran consideradas delictivas y crear o agravar penas más allá de las vigentes al momento de comisión del hecho, la Ley 27304 no es violatoria de esta garantía. Resulta irrelevante que el contenido de la declaración brindada en el marco del acuerdo de colaboración se refiera a hechos anteriores a la sanción de esta ley. Además, tampoco existe el derecho de los coimputados a no ser señalados por los arrepentidos ya que no existe el derecho adquirido a ser juzgado por un determinado procedimiento, toda vez que las leyes inaplicables por esta garantía constitucional son las que se refieren a delitos y penas, mas no las que estatuyen acerca de la manera de descubrirlos y perseguirlos.

Entonces, queda claro que ninguno de los argumentos críticos desarrollados en el presente trabajo logra demostrar la repugnancia clara e indudable de la Constitución con respecto al instituto del imputado colaborador de la Ley 27304. Algunos objetarán su moralidad, otros su utilidad, pero aquello es un examen de oportunidad, mérito y conveniencia política que, por tal, es extrajurídica y reservada a la prudencia del Poder Legislativo, ya que se mantiene dentro de los límites de nuestra Constitución Nacional.

En conclusión, la ley del arrepentido es constitucional.

\section{Bibliografía}

Aboso, G. E. (13 de octubre de 2017). La figura del arrepentido en el Derecho Penal Argentino. El Dial, DC2409. https://www.eldial.com/nuevo/index.asp.

Abou Assali, J. y Romero Villanueva, H. J. (2019). Apuntes sobre la figura del colaborador eficaz. Revista de Derecho Penal y Criminología, 9, 25-46.

Alén, L. H. (2018). La inconstitucionalidad de la ley del arrepentido 27.304 (y la nulidad de los acuerdos celebrados en función de ella). Revista de Derecho Penal y Criminología, VIII, 65-82.

Badeni, G. (2006). Tratado de Derecho Constitucional (Tomo II). La Ley.

Báez, J. C. (21 de agosto de 2003). El arrepentido: perfiles de la figura. Su regulación en la legislación nacional y en la Ley 25.742 para la prevención del secuestro de personas. La Ley Suplemento Actualidad, 21/AR/DOC/10541/2003. https://www.thomsonreuters.com.ar/.

Bernardini, L. y Nicolás, M. (2020). Imputado Delator y Delatado. La lógica del camaleón en 
las estrategias de defensa. Estudios sobre Jurisprudencia. https://jurisprudencia.mpd.gov.ar/ Estudios/2020.05.\%20Imputado\%20delator\%20y\%20delatado.pdf.

Cafferata Nores, J. I. (2018). Reflexiones iniciales. En Cafferata Nores, J. I. (Dir.), Discusión de ideas con relación a la ley del arrepentido. Interrogantes (pp. 4-6). Instituto de Derecho Procesal, Academia Nacional de Derecho y Ciencias Sociales de Córdoba. https://www.acaderc.org. ar/wp-content/blogs.dir/55/files/sites/55/2020/02/discusionleyarrepentido.pdf.

Carrió, A. D. (1994). Garantías constitucionales en el proceso penal. Hammurabi.

Charni, T. H. y Frezzini, M. A. (2019). Declaración del arrepentido: su conflicto con la garantía contra la autoincriminación. En Ale, A. S. y Beltracchi, P. (Coords.), Medios de prueba en el proceso penal. Prueba testimonial (Tomo 2, pp. 147-168). Hammurabi.

Creus, C. y Buompadre, J. E. (2013). Derecho penal. Parte especial (Tomo I). Astrea.

D’Alessio, A. J. (Dir.). (2004). Código Penal: Comentado y anotado: Parte Especial (arts. 79 a 306). La Ley.

Díaz Cantón, F. (2018). Breves notas críticas sobre la figura del "arrepentido”. Pensar en Derecho, 13, 19-29.

Donna, E. A. (2007). Derecho Penal: parte especial (Tomo II-B). Rubinzal Culzoni.

Fernández, G. A. (2016). El testimonio de un imputado como prueba de cargo. Análisis de la figura del arrepentido en los casos de corrupción. Revista de Derecho Procesal Penal, 2, 441-468.

Ferrer, A. (2018). Dos dilemas procesales de la ley 27.304. En Instituto de Derecho Procesal, Academia Nacional de Derecho y Ciencias Sociales de Córdoba, Discusión de ideas con relación a la ley del arrepentido. Interrogantes (pp. 46-56). https://www.acaderc.org.ar/wp-content/blogs.dir/55/files/sites/55/2020/02/discusionleyarrepentido.pdf.

Frezzini, M. A. (2020). Información aportada en el acto de la declaración indagatoria como elemento para evaluar la falta de riesgos procesales al momento de conceder una excarcelación. Su diferencia con la información aportada por el imputado como arrepentido. Revista de Derecho Penal y Criminología, 4, 189-203.

Godsey, M. A. (2005). Rethinking the Involuntary Confession Rule: Toward a Workable Test for Identifying Compelled Self-Incrimination. Faculty Articles and Other Publications, 92, 465-540. http://scholarship.law.uc.edu/fac_pubs/92.

Hairabedián, M. (15 de noviembre de 2016). Nueva legislación sobre los arrepentidos que no se arrepienten. El Dial, DC222D. https://www.eldial.com/nuevo/index.asp.

Hendler, E. (1998). La razonabilidad de las leyes penales: La figura del arrepentido. En Ouviña, G., Vitale, D. L., Bacigalupo, E., Palazzo, F., Sancinetti, M. A., Pessoa, N. R., Bustos Ramírez, J., Schünemann, B., Donna, E. A., Creus, C., De Rivacoba y Rivacoba, M., Luzón Peña, D. M., Righi, E., Maier, J. B. J., Moreno Hernández, M., Reyes Alvarado, Y., Hendler, E., Buteler (h.), J. A., Fernández, G. D.,... Malamud Goti, J., Teorías actuales en el Derecho Penal (pp. 393-404). Ad Hoc.

Joselow, M. (2019). Promise-Induced False Confessions: Lessons from Promises in Another Context. Boston College Law Review, 60(6). https://lawdigitalcommons.bc.edu/cgi/viewcontent. cgi? article $=3787 \&$ context $=$ bclr.

Lesch, H. H. (2016). El concepto de delito. Las ideas fundamentales de una revisión funcional. Marcial Pons. Llera, C. E. (2019a). Arrepentido y autoincriminación compulsiva. Revista de Derecho Penal y Procesal Penal, 2, 230-238. 
Llera, C. E. (2019b). Arrepentido y la garantía que protege contra la autoincriminación compulsiva. El suministro malicioso de información falsa o inexacta acogiéndose al beneficio del art. 41 ter del Cód. Penal (art. 276 bis del Cód. Penal). Su constitucionalidad. Institutas. Revista de Derecho Procesal, 9. https://ar.ijeditores.com/pop.php?option=articulo\&Has$\mathrm{h}=0 \mathrm{cf} 4 \mathrm{c} 4656 \mathrm{f} 72601 \mathrm{dbee67fa90bf94014.}$

Minoggio, D. (2019). La figura del "arrepentido" o imputado colaborador. Eficacia de la investigación vs. Garantías constitucionales. Revista de Derecho Penal y Criminología, 3, 107-117.

Neira, C. (1997). El arrepentido y el agente encubierto - Reflexiones acerca del "Proyecto de ley contra las actividades terroristas”. La Ley, 1997-B, 1431.

Observatorio de la Deuda Social Argentina. (2018). Valoraciones de la Democracia y Apatía Ciudadana (2010-2018). Estudio comparado entre CABA y otras áreas urbanas. Universidad Católica Argentina http://wadmin.uca.edu.ar/public/ckeditor/Observatorio\%20Deuda\%20Social/ Presentaciones\%202018/2018/2018-OBSERVATORIO-INFORME-DE-AVANCE-APATIA-CIUDADANA.pdf.

Pérez Arias, J. (2006). Juicio abreviado: acerca de las observaciones críticas que se le dirigen. Revista de la Asociación de Magistrados y Funcionarios de la Justicia de la Nación, (39/40). https:// ijeditores.com/articulos.php?idarticulo=48988\& print=2\#indice_7.

Quiroga Lavié, H., Benedetti, M. A. y Cenicacelaya, M. N. (2009). Derecho Constitucional Argentino (Tomo I). Rubinzal Culzoni.

Repetto, A. L. (15 de junio de 2007). La importancia del derecho y del derecho penal. El Derecho. Righi, E. (2015). Derecho Penal. Parte General. Abeledo Perrot.

Rusconi, M. (2018). Arrepentidos y justicia penal: ¿nuevas formas de combatir la criminalidad organizada o la Inquisición del nuevo milenio? Pensar en Derecho, (13), 9-18.

Sancinetti, M. A. (2016). Dictamen sobre proyectos de leyes, así llamados, de "Arrepentido" y de "Extinción de Dominio" (Explicaciones complementarias a la intervención del 3/8/2016, a disposición del H. Senado en versión taquigráfica de esa fecha). Revista de Pensamiento Penal. http://www.pensamientopenal.com.ar/doctrina/47338-dictamen-sobre-proyectos-leyes-asi-llamados-arrepentido-y-extincion-dominio.

Sebastián, E. (2018). La excarcelación del arrepentido. La Ley, 2018-A, 1-11.

Spolansky, N. E. (2001). El llamado arrepentido en materia penal. La Ley, 2001-F, 1434-1437.

Terragni, M. A. (1998). El "arrepentido" o "el testigo de la corona” y otras cuestiones conexas. Doctrina Judicial, XIV(16). https://www.terragnijurista.com.ar/libros/atc_o.htm.

Tomás de Aquino. (1993). Suma Teológica. Club de Lectores.

Uriburu, G. J. (2019). La perforación de los topes mínimos de las escalas penales. Análisis a partir de los casos Guffanti y Ríos. Forum, 7, 29-50.

Zorraquín Becú, R. (1988). Historia del Derecho Argentino (Tomo II). Perrot.

\section{Jurisprudencia citada}

\section{Corte Suprema de Justicia de la Nación}

Arancibia Clavel Enrique Lautaro s/homicidio calificado y asociación ilícita y otros -Causa $n^{\circ} 259$, 24/08/2004, Fallos: 327:3312.

Baldivieso, César Alejandro s/causa n 4733, 20/4/2010, Fallos: 333:405. 
Burrueco Mansilla, Rodolfo, en la causa que se le sigue ante los Tribunales Militares de la Nación, por hurto, 13/10/1917, Fallos: 126:280.

Cafés, Chocolates Águila y Productos Saint Hnos. S.A., 20/3/1961, Fallos: 249:343.

Casas Alejandro Esteban s/Homicidio Culposo, 03/05/2007, Fallos: 330:1975.

Don Julio Sánchez Viamonte, en autos con el doctor Emilio Giustinian, sobre falsedad, 29/04/1916, Fallos: 123:106.

Eduardo Mendoza, por falsificación de un manifiesto de Aduana, 28/10/1864, Fallos: 1:350.

El Atlántico diario s/infracción art. 23, ley 4664 -Mar del Plata-, 22/11/1971, Fallos: 281:177.

Fernández, Eduardo c/TA. La Estrella S.A. s/despido, 10/06/1992, Fallos: 315:1190.

García, María Isabel c/AFIP s/acción meramente declarativa de inconstitucionalidad, 26/03/2019, Fallos: 342:411.

García Monteavaro, Julio Efrain c/Amoroso y Pagano, 14/06/1957, Fallos: 238:60.

Geddes Hnos. y otros c/Provincia de Buenos Aires, 17/07/1902, Fallos: 95:327.

Gerstein, Myriam Noemí s/infracción ley 20.771, art. 2, inc. a), c) y d), 20/12/1988, Fallos: 311:2721.

Guillermo Olivar, por complicidad en el delito de rebelión; sobre fianza de juzgado y sentenciado y desacato, 01/05/1895, Fallos: 16:118.

Juan José Cincotta, 13/02/1963, Fallos: 255:18.

Montenegro, Luciano Bernardino, 10/12/1981, Fallos: 303:1938.

Paz, doctor José Clemente, su testamentaria, 20/05/1915, Fallos: 117:22.

Raisberg de Merenzon, Claudia Ethel s/suspensión, 04/05/1995, Fallos: 318:963.

Revello Carlos Agustín y otros s/abuso de autoridad en los términos del art. 248 del Código Penal-Causa $N^{\circ}$ 10503, 21/11/2006, Fallos: 329:5323.

Ruiz, Roque A. s/hurtos reiterados, 17/09/1987, Fallos: 310:1847.

Santoro, Cayetano c/Frias, Estela, 28/09/1916, Fallos: 124:122.

Spotorno, Ángel, 22/08/1938, Fallos: 81:288.

Zambrana Daza, Norma Beatriz s/Infracción a la Ley 23737, 12/08/1997, Fallos: 320:1717.

\section{Cámara Federal de Casación Penal}

De Vido, Julio Miguel y otros s/recurso de casación, Sala I, 30/11/2020, [CFP 9608/2018/100, Registro 1663/20].

Díaz Bessone, Ramón Gerardo s/Recurso de inaplicabilidad de ley, 30/10/2008, Plenario $\mathrm{N}^{\circ} 13$, Acuerdo nro. 1/08.

Legajo de arrepentido. Ferreyra, Claudio Marcelino por asociación ilícita art. 303 inc. 1, Sala IV, 5/6/2019, [FCB 058814/2017/31/CFC001, Registro 1140/19.4].

\section{Suprema Corte de los Estados Unidos}

Brady v. United States, 04/05/1970, 397 U.S. 742.

Bram v. US, 13/12/1897, 168 U.S. 532.

Lisenba v. California, 08/12/1941, 314 U.S. 219.

Malloy v. Hogan, 05/06/1966, 378 U.S. 1.

Miranda v. Arizona, 13/06/1966, 384 U.S. 436. 


\section{Corte Interamericana de Derechos Humanos}

Barrios Altos vs. Perú, Fondo, 14/03/2001.

Jenkins vs. Argentina, Excepciones Preliminares, Fondo, Reparaciones y Costas, 26/11/2019.

Romero Feris vs. Argentina, Fondo, Reparaciones y Costas, 15/10/2018.

Ruano Torres y otros vs. El Salvador, Fondo, Reparaciones y Costas, 05/10/2015.

Zegarra Marin vs. Perú, Excepciones Preliminares, Fondo, Reparaciones y Costas, 15/02/2017.

\section{Legislación citada}

Código Aduanero.

Código Penal de la Nación.

Código Procesal Penal de la Nación.

Código Procesal Penal Federal.

Convención Americana sobre Derechos Humanos.

Convención contra la Tortura y Otros Tratos o Penas Crueles, Inhumanos o Degradantes.

Convención de las Naciones Unidas contra la Corrupción.

Convención de las Naciones Unidas contra la Delincuencia Organizada Transnacional.

Convención Interamericana para Prevenir, Sancionar y Erradicar la Violencia contra la Mujer.

Convención Internacional sobre la Eliminación de todas las formas de Discriminación Racial.

Convención sobre la Eliminación de todas las formas de Discriminación contra la Mujer.

Convención sobre los Derechos de las Personas con Discapacidad y Protocolo facultativo.

Convención sobre los Derechos del Niño.

Declaración Americana de Derechos y Deberes del Hombre.

Declaración Universal de Derechos Humanos.

Ley 49 de Delitos cuyo juzgamiento compete a los Tribunales Nacionales, sancionada el 14 de septiembre de 1863. Registro Nacional de la República Argentina, tomo V, núm. 5968.

Ley 13985, BO 16/10/1950.

Ley 23737, BO 11/10/1989.

Ley 24424, BO 09/01/1995.

Ley 25241, BO 17/03/2000.

Ley 25246, BO 10/05/2000.

Ley 25632 BO 30/08/2002.

Ley 25742, BO 20/06/2003.

Ley 26097 BO 09/06/2006.

Ley 26364, BO 30/04/2008.

Ley 26549, BO 27/11/2009.

Ley 26679, BO 9/05/2011.

Ley 26683, BO 21/06/2011.

Ley 27148, BO 18/06/2015.

Ley 27156, BO 31/07/2015.

Ley 27304, BO 2/11/2016.

Ley 27401, BO 1/12/2017.

Pacto Internacional de Derechos Civiles y Políticos.

Proyecto de Código Penal presentado por Carlos Tejedor. 


\section{Otras fuentes}

Constitución de los Estados Unidos.

Dictamen de la Comisión de Justicia y Asuntos Penales y de Seguridad Interior y Narcotráfico del Senado de la Nación, Orden del Día N 605, 31/08/2016.

Observatorio de la Deuda Social Argentina, Universidad Católica Argentina (2018). Valoraciones de la Democracia y Apatía Ciudadana (2010-2018). Estudio comparado entre CABA y otras áreas urbanas. http://wadmin.uca.edu.ar/public/ckeditor/Observatorio\%20Deuda\%20Social/ Presentaciones\%202018/2018/2018-OBSERVATORIO-INFORME-DE-AVANCE-APATIA-CIUDADANA.pdf.

Versión taquigráfica de la Cámara de Senadores de la Nación 13a Reunión, 5ª Sesión ordinaria, 07/09/2016.

Versión taquigráfica e inserciones de la Sesión Ordinaria Especial de la Cámara de Diputados de la Nación del 23/06/2016. 
